Notes

\title{
MANUFACTURING CONVICTIONS: WHY DEFENDANTS ARE ENTITLED TO THE DATA UNDERLYING FORENSIC DNA KITS
}

\author{
JENNIFER N. MELLON
}

\section{INTRODUCTION}

When forensic DNA testing arrived in the courtroom, it was heralded as the "greatest advance in crime fighting technology since fingerprints." From the beginning, however, nonforensic scientists and defense lawyers expressed concern that enthusiasm for the new technology had outpaced forensic laboratory capabilities. ${ }^{2}$ This concern arose from the fact that many labs were suffering from chronically high error rates even before crime laboratories were asked to perform the highly sophisticated analysis forensic DNA testing requires. ${ }^{3}$ To

Copyright (C) 2001 by Jennifer N. Mellon.

1. William C. Thompson, Evaluating the Admissibility of New Genetic Identification Tests: Lessons from the "DNA War," 84 J. CRIM. L. \& CRIMINOLOGY 22, 22 (1993) (quoting People v. Wesley, 533 N.Y.S.2d 643, 644 (Sup. Ct. 1988)).

2. Edward J. Imwinkelried \& D.H. Kaye, DNA Typing: Emerging or Neglected Issues, 76 WASH. L. REV. 413, 413-14 (2001) (“[DNA's] suitability for the courtroom was bitterly contested. Significant questions were raised in the popular press, books from scientific publishers, law reviews, and, of course, in trial and appellate courts.").

3. Joseph L. Peterson et Al., Crime Laboratory Proficiency Testing Research Program 251 (1978) (providing the following error rates in state laboratories: $71.2 \%$ of laboratories erred in blood tests, $51.4 \%$ erred in matching paint samples, $35.5 \%$ erred in soil examinations, and $28.2 \%$ erred in firearms identifications). The Peterson survey explored only errors resulting from incompetence, not those "errors" resulting from analyst bias. The most clear example of bias is Fred Zain, a former director of the Division of Public Safety's serology division at the West Virginia state police crime laboratory. Zain was found to have willfully lied about test results produced by the state lab for years. In re Investigation of the W. Va. State Police Crime Lab., Serology Div., 438 S.E.2d 501, 503 (W. Va. 1993). Analyst bias also has been noted in the San Francisco Crime Lab. People v. Bokin, No. 168461, slip op. at 15 (Cal. Super. Ct. May 5, 1999) (holding DNA evidence inadmissible), available at http://www. scientific.org/distribution/archive/ca-v-bokin.pdf (on file with the Duke Law Journal). In its order, the court noted that Alan Keel, then the head of the San Francisco Crime Lab, demon- 
find out if labs suffer from similar error rates while performing forensic DNA analysis, defendants have sought extensive discovery of testing data. ${ }^{4}$ The laboratories performing DNA testing have resisted discovery.

The discovery conflicts surrounding forensic DNA testing moved into a new arena when state laboratories began using DNA kits prefabricated by private corporations. Commercial forensic DNA kits are like chemistry sets: they include all of the materials used in DNA testing and detailed instructions on how to produce results. ${ }^{6}$ The kits provide a protocol and ingredients, but the companies are generally reluctant to reveal information unnecessary to the step-by-step testing process. ${ }^{7}$ In fact, the companies provide so little information that analysts using kits have been compared to "the average person using a VCR - with no knowledge of the science that makes it work, but happy to push a button and get results."

strated an unacceptable degree of bias toward the prosecution. Id. The court described Keel's declaration in opposition to defense discovery as "beyond advocacy-it indicated a critical attitude toward the defense function in a criminal case." Id.

4. E.g., United States v. Yee, 129 F.R.D. 629, 636 (N.D. Ohio 1990) (granting the defendant's discovery motion for materials relating to DNA analysis of blood); State v. Dykes, 847 P.2d 1214, 1217-19 (Kan. 1993) (affirming the denial of the defendant's discovery motion for a DNA database); People v. Davis, 601 N.Y.S.2d 174, 175 (App. Div. 1993) (granting a new trial to the defendant on the basis of the trial court's refusal of access to the data underlying a DNA match); Spencer v. Commonwealth, 384 S.E.2d 785, 797 (Va. 1989) (asserting that the Commonwealth is not required to establish the reliability of incriminating DNA tests).

5. Thompson, supra note 1, at 96-100 (describing the efforts of prosecutors, the FBI, and private forensic laboratories to resist defense discovery). The fight over access to data held by the FBI grew particularly heated. Defense lawyers have accused John W. Hicks, the FBI's Assistant Director in Charge of the Laboratory Division, of attempting to destroy data relating to the FBI's forensic DNA program to avoid the possibility of defense discovery. William C. Thompson, Letter, Worthwhile DNA Questions, 77 JUdiCATURE 57, 57 (1993).

6. For instance, the D1S80 kit, a PCR (Polymerase Chain Reaction)-based system marketed by Perkin-Elmer Corporation includes preformulated D1S80 PCR Reaction mix, an allelic ladder to be used in interpreting the results, and the allele frequencies from randomly selected individuals (which are used to determine the significance of a match). Human Identity: AmpliFLP ${ }^{\mathrm{TM}}$ D1S80 PCR Amplification Kit and Associated Products, Applied Biosystems, at http://www.appliedbiosystems.com/fo/d1s80.html (last visited Sept. 29, 2000) (on file with the Duke Law Journal).

7. See, e.g., Tom Abate, Company's Trade Secrets Clash with a Judge's Need to Know: Court Wants Formula to DNA Test Kit but Perkin-Elmer Is Mum, S.F. CHRON, May 10, 1999, at B1 (reporting that a San Francisco judge decided not to admit the results from a DNA test kit because the company that manufactured the kit refused to reveal underlying data).

8. Doug Guthrie, Experts, Lawyers Differ on DNA Test's Reliability, GRAND RAPIDS PRESS, Sept. 6, 2000, at A13. Similarly, the kits have been described as a "shake 'n' bake operation." Abate, supra note 7, at B1. Scientists have expressed concern that an analyst's lack of ac- 
Thus, when defendants seek to discover information about a kit, they must subpoena it from the private corporation that makes the kit. Currently, the primary manufacturers of the kits are Promega ${ }^{9}$ and Perkin-Elmer Corporation (PE) ${ }^{10}$ successors in interest (at least partly) to DNA typing products originally developed by the Cellmark and Cetus corporations, respectively. ${ }^{11}$ Like forensic laboratories, PE and Promega initially resisted defense efforts to obtain discovery of data. ${ }^{12}$ Promega, however, eventually published the data that defendants sought. ${ }^{13} \mathrm{PE}$, while making limited concessions in individual cases, has continued to fight discovery in other cases. ${ }^{14}$

cess to more information will impact his ability to correctly perform testing. Eric S. Lander, Invited Editorial: Research on DNA Typing Catching Up with Courtroom Application, 48 AM. J. HUM. GENETICS 819, 820 (1991) (questioning whether the forensic laboratories know enough about the variability of their own procedures to devise appropriate quantitative criteria for a match).

9. Promega is a life sciences corporation. It is headquartered in Madison, Wisconsin, and reports annual sales in excess of $\$ 100$ million. Press Release, Promega Corp., Promega Corporation Announces Plan to Significantly Support Admissibility of DNA Testing in U.S. Judicial System (July 19, 2000), available at http://www.promega.com/pressrelease/00719dnatest.htm (on file with the Duke Law Journal).

10. The Perkin-Elmer Corporation (PE) is a worldwide supplier of systems for life science research and related applications. Press Release, Perkin-Elmer Corp., New DNA-Typing System Offers Powerful Technology for Determining Identity in Criminal and Accident Investigations (Feb. 11, 1998), available at http://www.pe-corp.com/press/prc5411.html (on file with the Duke Law Journal). A 1999 survey of forensic labs in all fifty states found that seventy-five percent of labs used PE test kits. Doug Guthrie, DNA Test Maker Will Reveal Formula at Hearing, GRAND RAPIDS PRESS, Sept. 1, 2000, at C1.

11. People v. Moevao, No. 168277, slip op. at 20 (Cal. Super. Ct. July 24, 2000) (granting the plaintiff's motion to admit DNA evidence), available at http://www.denverda.org/ legalResource/moevao.pdf (on file with the Duke Law Journal).

12. In State v. Pfenning, No. 57-4-96 (Vt. Dist. Ct. Apr. 26, 2000), the trial court excluded the results of both PE and Promega kits because the kit makers had not released enough information for the court to be sure of the kits' reliability under Daubert v. Merrell Dow Pharmaceuticals, Inc., 509 U.S. 579 (1993). See also State v. Dishmon, Nos. 99047345, 99069306, 99079650, slip op. at 13 (Minn. Dist. Ct. Mar. 3, 2000) (noting that in resisting the defense subpoena, "PE Biosystems claims trade secrets, overwhelming expense and effort[,] and[,] reading between the lines[,] claims that the material is not needed here").

13. Press Release, Promega Corp., supra note 9.

14. In People v. Cavin, No. 00-4395-NY (Mich. Cir. Ct. Oct. 18, 2000), a Michigan trial court case, PE agreed to reveal its primer sequences provided all parties involved agreed to a protective order. $I d$., slip op. at 14 (admitting DNA evidence). In the same case, however, PE refused to release its developmental validation data. Id. at 18. In many cases, PE has refused to release either its primer sequences or its developmental validation data. See supra note 12 and accompanying text. 
In fighting discovery, both PE and Promega have advanced (and PE continues to advance) various arguments. ${ }^{15}$ They have relied most heavily on the argument that the information sought is proprietary and thus protected under the trade secret privilege. ${ }^{16}$ Alternatively, they have contended that defense subpoenas of data are invalid because the burden the corporations would suffer in gathering requested information outweighs the defendant's need for the information. ${ }^{17}$

This Note argues that trial courts are wrong to admit the results of forensic DNA testing when the defendant lacks access to the scientific data supporting the testing method. Part I describes the types of information being denied to defendants and how that information could be used to challenge the kits' reliability in court. Part II describes the current criminal discovery regime and explains how it fails

15. One Colorado trial court noted that "PE has resisted releasing its developmental data claiming that the data was unavailable, that it had never been systematically recorded, that it was scattered throughout various departments at the company and [that] its collection at this time would be unduly burdensome." People v. Shreck, No. 98CR2475, slip op. at 13 (Colo. Dist. Ct. 2000) (granting the defendant's motion to bar DNA evidence derived from multiplex kits), available at http://www.scientific.org/distribution/archive/Shreck.doc (on file with the Duke Law Journal). The Colorado Supreme Court later vacated the decision. People v. Shreck, 22 P.3d 68, 81 (Colo. 2001). In at least two cases, trial courts have held kit results admissible even though the kit maker refused to comply with a defense subpoena for data relating to the kit. The court in Dishmon held that the denial of discovery was not significant to admissibility of the kit because (1) the State could make the required showing of admissibility of the results without the discovery and (2) the defendant had access to other information and thus did not suffer any prejudice that would violate his right to a fair trial. Dishmon, Nos. 99047345, 99069306, 99079650, slip op. at 15. As this Note argues, however, the Dishmon court makes questionable assumptions as to the sufficiency of the evidence to which the defendant was given access. Another court found a subpoena unenforceable because the burden on the kit maker substantially outweighed the alleged demonstrated need for the information. People v. Bertsch, No. 94F07295 (Cal. Super. Ct. Oct. 20, 1999).

The Dishmon court justified its holding as follows: "The system is like a Model A Ford. Thousands of owners can tell us it works even if Henry Ford can't or won't explain it." Dishmon, Nos. 99047345, 99069306, 99079650, slip op. at 15. A PE expert witness made a similar observation: "There are components in your car you don't know anything about[.] Your concern as a consumer is, 'Does this get me from one place to another?"' Abate, supra note 7, at B1.

16. State v. Lynch, No. CR 98-11390, slip op. at 5 (Ariz. Super. Ct. Aug. 17, 1999) ("[I]t is the position of the Perkin-Elmer Corporation to preserve their proprietary interest in the Profiler/Cofiler testing kits."); People v. Hill, 107 Cal. Rptr. 2d 110, 116 (Ct. App. 2001) ("The Perkin-Elmer Corporation claimed that the [validation] data was proprietary."); Abate, supra note 7, at B1. A seller of DNA kits for PE explained the corporation's fears: "'In one case where [PE] turned over similar proprietary information to a court in Boston, a defense expert published the data." Id. According to the seller, the publication allowed competitors to copy the kit and undercut PE's sales. Id.

17. Dishmon, Nos. 99047345, 99069306, 99079650, slip op. at 13. 
to create a right of access to data held by third parties, data that is important in fully examining the reliability of forensic DNA kits. Part III examines the arguments against granting defense discovery of the data, and concludes that none of the arguments against expanded discovery are persuasive. Finally, Part IV argues that the current hindrances to discovery are not only bad policy, but also constitutionally defective. Although most courts to consider this question have not found lack of discovery to have constitutional implications, discovery of this data is crucial to protect defendants' rights under the Compulsory Process, Confrontation, and Due Process Clauses.

\section{Challenging the Reliability of ForensiC DNA Kits ${ }^{18}$}

Criminal defendants have sought access to developmental validation data and primer sequences from DNA kit makers to effectively challenge the results of DNA testing in court. The discussion in this Part begins by describing in general terms the two ways in which a defendant can challenge the reliability of scientific evidence: challenging its admissibility at a pretrial admissibility hearing and challenging its weight before the jury at trial. The discussion then moves to specifics, describing the types of data that defendants are seeking from kit makers and how that evidence would assist defendants in making those challenges.

\section{A. Admissibility}

Under the law of evidence, trial courts must evaluate the admissibility of scientific evidence. ${ }^{19}$ Although the required threshold showing differs among jurisdictions at least formally, ${ }^{20}$ the underlying concern of courts in all jurisdictions in evaluating the admissibility of evidence is trustworthiness, also called "evidentiary reliability." 21

18. For my understanding of these issues, I am indebted to Michael Burt of the San Francisco Public Defender's Office.

19. David L. Faigman et al., Legal Standards for the Admissibility of Scientific Evidence (Draft Chapter of Forthcoming Second Edition of MODERN SCIENTIFIC EVIDENCE: THE LAW AND SCIENCE OF EXPERT TESTIMONY), 78 A.L.I.-A.B.A. 33, 36 (2001).

20. Id. at $36-37$.

21. Daubert v. Merrell Dow Pharms., Inc., 509 U.S. 579, 590-91 n.9 (1993). 
There are two predominant tests used to determining the reliability of scientific evidence: the Daubert ${ }^{22}$ test and the Frye $e^{23}$ test.

1. Daubert. In the 1993 case Daubert v. Merrell Dow Pharmaceuticals, Inc. ${ }^{24}$ the Supreme Court held that the Federal Rules of Evidence superseded the traditional standard for determining the admissibility of scientific evidence. ${ }^{25}$ Under Rule 702, scientific evidence is admissible only if it is shown to be reliable. ${ }^{26}$ The Court explained that evidence is reliable only where it is the product of sound scientific methodology ${ }^{27}$ and announced a nonexclusive list of factors by which a particular methodology may be evaluated. ${ }^{28}$ Those factors are: (1) whether the underlying theory or technique can be and has been tested, (2) whether the underlying theory or technique has been subjected to peer review and publication, (3) the underlying theory's known or potential rate of error, and (4) the general acceptance of the underlying theory in the scientific community. ${ }^{29}$ Thus, in Daubert jurisdictions, trial judges clearly are expected to determine for themselves the reliability of evidence and exclude evidence found to be unreliable.

At least one state trial court has held that DNA test results produced by Profiler Plus and PowerPlex kits are inadmissible on grounds of unreliability under Daubert..$^{30}$ The Pfenning court in Vermont worried specifically about the fact that the manufacturers of the DNA kits had failed to disclose to both the defense and the scientific community at large the developmental validation studies and the

22. The Supreme Court has explained the Daubert test in three cases to date: Kumho Tire Co. v. Carmichael, 526 U.S. 137, 141-58 (1999); General Electric Co. v. Joiner, 522 U.S. 136, 142 (1997); and Daubert, 509 U.S. at 589-98.

23. The Frye test is named after the case in which it was first articulated, Frye v. United States, 293 F. 1013 (D.C. Cir. 1923).

24. 509 U.S. 579 (1993).

25. Daubert, 509 U.S. at 587.

26. Id. at 590 .

27. $I d$.

28. Id. at 593-94.

29. Id.

30. State v. Pfenning, No. 57-4-96, slip op. at 68 (Vt. Dist. Ct. Apr. 26, 2000). It should be noted that this was before the maker of PowerPlex, Promega, published its primer sequences and validation data. In fact, Promega did so in direct response to the Pfenning decision. Press Release, Promega Corp., supra note 9. 
primer sequences used to amplify the DNA before typing it. ${ }^{31}$ In discussing the refusal of kit makers to reveal information about the kits, the court wrote:

[T] he failure of the manufacturers of DNA testing systems to disclose the primer sequences they have created to permit amplification of DNA is problematic from the perspective of scientific knowledge and, consequently, validation. It is more than problematic, it is anti-scientific in that it inhibits the ability of scientists in the field (including defense experts) to test the manufacturers' claims. Although the Court understands that the manufacturers believe they need to maintain as confidential what they consider to be proprietary information, in the case of new technology, it delays acceptance by the courts. ${ }^{32}$

Other courts in Daubert jurisdictions have not agreed with the above analysis and have instead held the results of DNA tests kits admissible despite the kit makers' refusal to publish certain data. ${ }^{33}$ For example, the Colorado Supreme Court recently held that results produced by kits ought not even be subject to Daubert admissibility hearings because they are merely applications of technology that has already been accepted. ${ }^{34}$ However, as the Vermont decision makes clear, the issue of the admissibility of the test results is not yet settled.

31. Pfenning, slip op. at 49,52 .

32. Id. at 49. In direct response to the decision in Pfenning, Promega decided to forgo its trade secret privilege claim and reveal both its validation data and the sequences of the primers included in its kits. Press Release, Promega Corp., supra note 9. In its release, Promega discussed the holding in Pfenning and its national repercussions. "Within weeks of the Vermont decision, the issue gained momentum in Colorado, California, Florida, Nevada and Massachusetts.... Many other cases are expected as defense attorneys move rapidly to cite the Vermont ruling." Id. In response to the coming challenges, Promega chose to become "the first DNA test manufacturer in the industry to make this unprecedented disclosure." Id. As of the date of this publication, PE has not followed Promega's lead and continues to fight discovery.

33. E.g., People v. Shreck, 22 P.3d 68, 81 (Colo. 2001) (holding that the results of Profiler Plus and Cofiler kits are admissible based on numerous studies, widespread information, popular use, and acceptance by other courts).

34. Id. ("Questions as to the reliability of the particular type of . . kit go to the weight of the evidence, rather than its admissibility."). 
2. Frye. Until the Supreme Court's decision in Daubert, the standard used by federal courts ${ }^{35}$ and most state courts ${ }^{36}$ in determining the admissibility of scientific evidence was the Frye test. ${ }^{37} \mathrm{Al}-$ though some states have chosen to adopt the new federal standard announced in Daubert, many states, including California, Florida, Michigan, and New York, have reaffirmed their allegiance to Frye. ${ }^{38}$ The District of Columbia Circuit Court of Appeals first articulated the Frye standard: "While courts will go a long way in admitting expert testimony deduced from a well-recognized scientific principle or discovery, the thing from which the deduction is made must be sufficiently established to have gained general acceptance in the particular field in which it belongs." ${ }^{39}$ The theory behind Frye is that general acceptance of scientific methodology serves as a surrogate for its reliability. ${ }^{40}$

Although Frye could be read to require that trial courts merely confirm that a majority of the relevant scientific community's members supports the underlying principle at issue, many jurisdictions require a more substantive determination of reliability. For example, in Florida trial courts must consider the "quality, as well as quantity, of the evidence supporting or opposing a new scientific technique." 41 To determine the quality of evidence, judges must make at least a limited inquiry into its reliability. Furthermore, Daubert's stricter standards

35. E.g., United States v. Skeens, 494 F.2d 1050, 1053 (D.C. Cir. 1974) (“[Frye] has been followed uniformly in this and other Circuits.").

36. E.g., Reed v. State, 391 A.2d 364, 368 (Md. 1978) ("This criterion of 'general acceptance' in the scientific community [the Frye test] has come to be the standard in almost all of the courts in the country which have considered the question of the admissibility of scientific evidence.").

37. 293 F. 1013 (D.C. Cir. 1923).

38. David E. Bernstein, Frye, Frye, Again: The Past, Present, and Future of the General Acceptance Test, 41 JURIMETRICS J. 385, 386-87 (2001) ("Frye is ... not only alive, but it is the plurality rule in state courts, which are the venue for the vast majority of litigation.").

39. Frye, 293 F. at 1014.

40. E.g., State ex rel. Collins v. Superior Court, 644 P.2d 1266, 1282 (Ariz. 1982) ("Frye . . [is] a general test of reliability."); Hadden v. State, 690 So. 2d 573, 578 (Fla. 1997) (affirming the court's adherence to the Frye test on the basis that courts should "not permit cases to be resolved on the basis of evidence for which a predicate of reliability has not been established").

41. Brim v. State, 695 So. 2d 268, 272 (Fla. 1997) (quoting People v. Leahy, 882 P.2d 321, 336 (Cal. 1994)). Similarly, when federal courts were still using Frye, the Sixth Circuit deemed "general acceptance as being nearly synonymous with reliability." United States v. Franks, 511 F.2d 25, 33 n.12 (6th Cir. 1975). 
have caused many Frye jurisdictions to take the trial court's gatekeeper role more seriously, resulting in greater attention to indicia of reliability traditionally outside Frye's scope of inquiry. ${ }^{42}$

Like trial courts in Daubert jurisdictions, trial courts in Frye jurisdictions need not always hold an evidentiary hearing on the admissibility of scientific evidence. Frye courts need do so only where the scientific methodology underlying proffered evidence is novel. ${ }^{43} \mathrm{Sev}$ eral courts have held that the evidence produced by DNA kits is not novel because kits are merely tools for carrying out accepted methodology. ${ }^{44}$ For example, in People v. Hill, a California appellate court rejected the argument that each new test kit must, as a matter of law, be subjected to a Frye hearing to determine its scientific reliability. ${ }^{45}$ Nonetheless, in most Frye jurisdictions courts have not yet decided whether particular models of DNA kits require Frye hearings, so trial courts are conducting hearings to avoid reversal. For example, in Florida, the trial court in State v. Yisrael ${ }^{46}$ conducted a Frye hearing to determine the reliability of the Profiler Plus and Cofiler Kits. ${ }^{47}$ Similarly, in Michigan, the trial court in People v. Phillips ${ }^{48}$ held that a Frye hearing was required because "[n]ew techniques applying generally accepted principles must themselves come to be generally accepted before their results may be received into evidence."

Although it is unclear if any jurisdictions will end up requiring Frye hearings for particular models of DNA kits, it is clear that trial courts in some jurisdictions are conducting such hearings. Furthermore, trial courts retain broad "latitude in deciding [how] to test an

42. Bernstein, supra note 38, at 393 ("[T]he stringent criteria established by the Daubert trilogy have helped to cause a welcome expansion and tightening of the general acceptance test in Frye jurisdictions.").

43. E.g., People v. Kelly, 549 P.2d 1240, 1244-45 (Cal. 1976) (explaining that a Frye hearing must be conducted only where the proffered evidence is the result of a "new scientific technique").

44. People v. Hill, 107 Cal. Rptr. 2d 110, 118 (Ct. App. 2001); State v. Russell, 882 P.2d 747, 768 (Wash. 1994).

45. 107 Cal. Rptr. 2d at 118. Courts in Minnesota also have held that no Frye hearing is required for particular kits where the underlying principles of the kits have been generally accepted. E.g., State v. Kirkendahl, No. 00044987, slip op. at 15 (Minn. Dist. Ct. Jan. 16, 2001) (denying the defendant's motion to suppress DNA evidence).

46. No. 99-20176CF10A (Fla. Cir. Ct. Aug. 8, 2000) (denying the defendant's motion to suppress DNA evidence).

47. Id., slip op. at 3 .

48. No. 00-02025-FC (Mich. Cir. Ct. Oct. 20, 2000).

49. Id., slip op. at 6 . 
expert's reliability, and to decide whether or when special briefing or other proceedings are needed to investigate reliability." ${ }^{50}$ Where trial courts choose to hold Frye hearings on particular models of DNA kits, evidence of the kits' reliability will determine their admissibility.

\section{B. Weight}

Even if courts decide not to hold hearings as to the admissibility of DNA kit results, defendants still will have the opportunity to challenge the reliability of the evidence before the jury at trial. All evidence related to reliability could be used by the defendant to challenge the weight given to the evidence by the jury, so long as the evidence is admissible. ${ }^{51}$ In holding that no Daubert hearing was required for particular models of DNA kits, the Colorado Supreme Court noted that all evidence bearing on the kits' reliability should "go to the weight of the evidence, rather than its admissibility.",52

\section{Data Underlying Forensic DNA Kits and Kit Reliability}

Before addressing the ways in which the reliability of the kits is in question, it is important to note that many of the principles and methodologies underlying forensic DNA testing are no longer in dispute. ${ }^{53}$ Most importantly, all courts now accept the proposition that the structure of an individual's DNA is both constant and unique and thus may be used to match biological evidence at a crime scene with

50. Kumho Tire Co. v. Carmichael, 526 U.S. 137, 152 (1999).

51. Edward J. Imwinkelried, Trial Judges-Gatekeepers or Usurpers? Can the Trial Judge Critically Assess the Admissibility of Expert Testimony Without Invading the Jury's Province to Evaluate the Credibility and Weight of the Testimony?, 84 MARQ. L. REV. 1, 30 (2000) ("The testimony submitted to the judge under Daubert because it is relevant to admissibility will also be logically relevant to the weight of the testimony, if admitted.").

52. People v. Shreck, 22 P.3d 68, 81 (Colo. 2001) (holding that the results of Profiler Plus and Cofiler kits are admissible under Colo. R. Evid. 702).

53. Imwinkelried \& Kaye, supra note 2, at 414 ("Today, the controversy over the scientific validity of forensic DNA testing has largely dissipated...."). Basic introductions to genetics and molecular biology may be found in many textbooks. E.g., I. EDWARD ALCAMO, DNA TECHNOLOGY 21-39 (2d ed. 2001). In addition, the National Research Council has published two volumes on forensic DNA technology and its legal implications. Both volumes contain short explanations of genetics and DNA typing. NAT'L RESEARCH COUNCIL, DNA TECHNOLOGY IN FORENSIC SCIENCE 1-8 (1992) [hereinafter NRC, DNA TECHNOLOGY]; NAT'L RESEARCH Council, The Evaluation OF Forensic DNA Evidence 60-74 (1996) [hereinafter NRC, EvALUATION]. 
an individual. ${ }^{54}$ Courts also have accepted certain specific methods of typing DNA, that is, characterizing a segment of DNA according to either its sequence or length. ${ }^{55}$ DNA typing allows samples of DNA to be compared, and thus allows analysts to determine that a suspect and a biological sample share the same DNA profile.

The dominant methods of DNA typing now rely on Polymerase Chain Reaction, or PCR, which has been almost unanimously approved as an admissible methodology. ${ }^{56} \mathrm{PCR}$ is an extraordinarily powerful means of replicating a chosen segment of a DNA sample, thus allowing more sophisticated tests to be performed. ${ }^{57}$ First, the technician extracts DNA from cells, and, using heat instead of enzymes, divides the strands from each other. ${ }^{58}$ The technician then adds a primer, a short piece of DNA, to the single strands. ${ }^{59}$ The primer "marks" the section on the DNA molecule that will be amplified. $^{60}$ The enzyme polymerase is added to the primer-DNA mixture. ${ }^{61}$ The polymerase, like naturally occurring enzymes that result in the DNA replication required to create new cells, creates a new complementary strand to bond with each of the original

54. William C. Thompson \& Simon Ford, DNA Typing: Acceptance and Weight of the New Genetic Identification Tests, 75 VA. L. REV. 45, 61 (1989).

55. For example, the first generation DNA test relied on restriction fragment length polymorphisms (RFLP). 2 PAUL C. GIANNELli \& EDWARD J. IMWINKELRIED, SCIENTIFIC EVIDENCE $\S 18-3(\mathrm{~A})$, at 10 (3d ed. 1999). The RFLP technique measures the length of certain DNA segments in each sample. These DNA segments are a sequence of repetitious base pairs called VNTRs (variable number of long tandem repeats). Id. The alleles of these loci differ in the number of repeats and in the size of the loci as a whole. Id. VNTRs are not genes; that is, they have not yet been determined to be associated with any traits. Id. $\S 18-3(\mathrm{~A})$, at 11 . This makes them particularly suited for forensic testing because non-trait producing areas of gene molecules are less likely to be influenced by natural selection, which leads to homogenization of base-pair sequences within populations. NRC, EVALUATION, supra note 53, at 14. The more common a base-pair sequence is, the less useful it is for forensic identification. Id. at 15 .

56. Imwinkelried \& Kaye, supra note 2, at 458.

57. The PCR technique was first developed at the Cetus Corporation in 1985. George F. Sensabaugh \& Cecilia von Beroldingen, The Polymerase Chain Reaction: Application to the Analysis of Biological Evidence, in FORENSIC DNA TECHNOLOGY 63, 63-64 (Mark A. Farley \& James J. Harrington eds., 1991). The scientist who developed it, Dr. Kary Mullis, won a Nobel Prize for his work. For a more complete discussion of the PCR technique, see generally KARY Mullis, Dancing NaKed in the Mind Field (1998); Paul Rabinow, MaKing PCR: A STORY OF BIOTECHNOLOGY (1996).

58. Sensabaugh \& von Beroldingen, supra note 57, at 64-66.

59. Id.

60. $I d$.

61. Id. 
strands. ${ }^{62}$ The process is repeated until large amounts of DNA are created. After PCR, the DNA may be analyzed with both sequencebased methods ${ }^{63}$ and length-based methods. ${ }^{64}$ Furthermore, PCRSTR, ${ }^{65}$ the method used by PowerPlex, Profiler Plus, and Cofiler, and promoted by the FBI as part of its Standardization Project, is also being rapidly accepted by courts.

Even though courts have accepted the basic science underlying forensic DNA testing, not all of them have accepted that commercially produced forensic DNA testing kits are reliable. ${ }^{66}$ To effectively challenge kits' reliability, defendants need the following types of data.

1. Developmental Validation Studies. Developmental validation determines the limitations of a new technology, such as what kinds of errors a technology is prone to and what types of precautions must be

62. $I d$.

63. Sequence variant-based tests look at differences in the actual sequence of bases at a specific location on the DNA strands. Id. at 66-67. Examples of sequence-based tests include the dot blot and reverse dot blot procedures. NRC, DNA TECHNOLOGY, supra note 53, at 42. To perform the dot blot method, the analyst adds a sequence-specific probe to dissociated strands of PCR-produced DNA. Id. The probe hybridizes with the PCR-produced DNA only if there is perfect complimentarity. The reverse dot blot method is quite similar; instead of adding probes to the PCR-produced DNA, the PCR-based DNA is added to a nylon membrane containing sequence-specific probes. $I d$. When the probe and the amplified DNA bind, the location of the binding appears colored because of a chemical tag that is added to the DNA during the amplification process. 2 GIANNELLI \& IMWINKELRIED, supra note 55, § 18-3(C), at 18. Supporters of the dot blot and reverse dot blot methods often argue that they are more straightforward because they provide a yes or no answer on the question of the presence of a particular sequence, as opposed to a measurement of length. CONGRESS OF THE UNITED STATES, OFFICE of TeCH. Assessment, Genetic Witness: ForensiC Uses of DNA TESTS 48 (1990). However, interpretation of the results is highly dependent on the intensity of the color of the dot produced. $I d$.

64. 2 GIANNELLI \& IMWINKELRIED, supra note 55, § 18-3(C), at 20.

65. PCR-STR first uses PCR to increase the amount of DNA available and then types the DNA according to the length of short-tandem repeats (STR), areas of the DNA molecule in which a single base pair is repeated over and over again. Short tandem repeats are, in effect, very short VNTRs, which are described, supra, at note 55. PCR-STR allows the analyst to amplify multiple loci at once, in a technique called multiplexing. 2 GIANNELLI \& IMWINKELRIED, supra note $55, \S 18-3(\mathrm{C})$, at 21 . It is the discriminatory power presented by multiplexing that led the FBI to choose STR as the standard typing method of the national Offender Database Information System (CODIS). Id. $\S 18-3(\mathrm{C})$, at 23.

66. Imwinkelried \& Kaye, supra note 2, at 459 ("The newer technologies are gaining judicial approval, but a court should not confer approval until it is satisfied that the specific technology satisfies the applicable standard."). 
taken to ensure that errors do not occur. ${ }^{67}$ Defendants seek access to data produced in developmental validation studies to ensure, on the most basic level, that developmental validation was in fact performed. It is uncontroverted that developmental validation determines whether a given method or kit produces accurate, reliable results. ${ }^{68}$ As the first National Research Council report on forensic DNA technology noted, "[t]here is no scientific dispute about the validity of the general principles underlying DNA typing .... However, a given DNA typing method might or might not be scientifically appropriate for forensic use. ${ }^{\circ 9}$ As a result, the report recommends that any new DNA typing method, or variation on an existing method, be rigorously tested to determine its reliability. ${ }^{70}$ The report's recommendation has been seconded by both the Technical Working Group for DNA Analysis Methods (TWGDAM) ${ }^{71}$ and the DNA Advisory Board

67. DNA Advisory Board Quality Assurance Standards for Forensic DNA Testing Laboratories, at Definition (ff), at http://www.cstl.nist.gov/biotech/strbase/dabqas.htm (last visited Jan. 4, 2000) (on file with the Duke Law Journal) [hereinafter Quality Assurance Standards]. It is important to distinguish between developmental validation and internal validation. Internal validation ensures that tests function appropriately in a specific laboratory; it does not seek to discover all of the limits of a particular technology. Id. Several courts in addressing defense subpoenas for developmental validation have held that the information is not required because the defendants already had access to internal validation studies. E.g., State v. Dishmon, Nos. 99047345, 99069306, 99079650, slip op. at 15 (Minn. Dist. Ct. Mar. 3, 2000) (holding that the defense had no need for developmental validation data because the "BCA lab [the Minnesota state crime lab] has validated the system as have other labs").

68. State v. Pfenning, No. 57-4-96, slip op. at 49 (Vt. Dist. Ct. Apr. 6, 2000).

69. NRC, DNA TECHNOLOGY, supra note 53, at 51. The National Research Council reports on forensic DNA are highly influential. The National Research Council is the research arm of the National Academy of Sciences, which was established by President Lincoln as a body that would assist the government in undertaking research on important and controversial scientific issues. Id. at vi. The first report, DNA Technology in Forensic Science, was authored by a committee of scientists in the fields of population and molecular genetics, forensic science, legal academics, ethicists, and United States District Judge Jack B. Weinstein. Id. at 173-176. The report was peer reviewed by a group other than the authors, and the final report was written and approved by the Committee as a whole. $I d$. at ii.

70. Id. at 72 .

71. TWGDAM Guideline 4.1.2 states that "[v]alidation studies must have been conducted by the DNA laboratory or scientific community prior to the adoption of a procedure by the DNA laboratory." Technical Working Group on DNA Analysis Methods, Guidelines for a Quality Assurance Program for DNA Analysis, CRIME LAB. Dig., Apr. 1995, at 21, 25 [hereinafter TWGDAM]. TWGDAM is a group of government and private forensic scientists that publishes its guidelines to ensure the "quality, integrity, and reliability of the DNA typing data and its presentation through the implementation of a detailed quality assurance (QA) program." Id. at 22. According to the second report published by the National Research Council, The Evaluation of Forensic DNA Evidence, these guidelines "define currently accepted practice." NRC, EVALUATION, supra note 53, at 24. 
(DAB). ${ }^{72}$ Furthermore, the National Institute of Standards and Technology has addressed STR systems like Profiler Plus, Cofiler, and PowerPlex specifically: "Before a new STR system or STR multiplex may be routinely employed in human identity testing it should be extensively validated to insure reliability of results." ${ }^{\text {,73 }}$ Thus, discovery could reveal that the required validation has not in fact been performed. ${ }^{74}$

Even if discovery shows that the kits were appropriately developmentally validated, the data produced in that process could reveal weaknesses of a particular kit model. For example, specific DNA tests are associated with specific artifacts. ${ }^{75}$ Artifacts are byproducts of the testing process that could be mistaken for evidence of a specific genetic makeup. ${ }^{76}$ During developmental validation, the kit should be "rigorously characterized with respect to the types of possible artifacts, the conditions under which they are likely to occur, the scientific controls for detecting their occurrence, and the steps to be taken when they occur." 77 The data produced by this study would thus help

72. DAB Standard 8.1 states: "The laboratory shall use validated methods and procedures for forensic casework.... Novel forensic DNA methodologies shall undergo developmental validation to ensure the accuracy, precision and reproducibility of the procedure." Quality Assurance Standards, supra note 67. DAB was established by the DNA Identification Act of 1994, Pub. L. No. 103-322, § 210301, 108 Stat. 1796, 2065, which established a federal framework for setting national standards on quality assurance and proficiency testing. The framework involved the creation of a DNA Advisory Board, whose members were to be appointed by the FBI from a list of nominations made by the National Academy of Sciences and professional societies representing the forensic community. NRC EVALUATION, supra note 53, at 24. The standards DAB issued were approved by the Director of the FBI and took effect on October 1, 1998. See Quality Assurance Standards, supra note 67.

73. John M. Butler \& Dennis J. Reeder, Validation Studies on STR Systems, at http://www. cstl.nist.gov/biotech/strbase/valid.htm (last visited on Jan. 2, 2000) (on file with the Duke Law Journal).

74. Misrepresentation of in-house scientific studies by biotechnology corporations has occurred in the past. A district court invalidated Roche's patent on the AmpliTaq ${ }^{\mathrm{TM}}$ DNA polymerase enzyme after finding that Cetus and Roche lied about scientific studies they performed. Hoffman-La Roche, Inc. v. Promega Corp., No. C-93-1748, 1999 WL 1797330, at *28 (N.D. Cal. Dec. 7, 1999). "There is reason to be skeptical of entrusting any important regulatory matters to a self-regulating organization .... There has been a notable dearth of published research in forensic DNA testing by scientists unconnected to the companies that market the tests." NRC, DNA TECHNOLOGY, supra note 53, at 162.

75. For example, RFLP testing is subject to such artifacts as band shifting, in which DNA samples move at different speeds, resulting in shifted patterns that do not accurately reflect the DNA sample's genotype. NRC, DNA TECHNOLOGY, supra note 53, at 54.

76. Id.

77. Id. 
the defense recognize artifacts that the analyst may have misinterpreted, know whether the laboratory used the proper controls to detect the occurrence of artifacts, and understand whether the analyst responded properly to signs that an artifact may have occurred.

The developmental validation data also would reveal the kit's ability to discern the results of environmental influences on the sample. According to TWGDAM guideline 4.1.5.6, developmental validation studies must include environmental studies, "so that the effects of factors such as matrix, age, and degradative environment (temperature, humidity, UV) on a sample are considered." 78 The data produced by the developmental validation studies would reveal the kit's ability to distinguish between true results of the DNA analysis and results that reflect environmental degradation.

2. Primer Sequences. The primer sequences are as material as developmental validation to the defense's case that the kits are unreliable. Primers are used in PCR, the amplification step of DNA testing. ${ }^{79}$ DAB guideline 4.1 .4 requires that " $[\mathrm{t}]$ he DNA primers . . . selected for use in the forensic DNA analysis must be readily available to the scientific community." traordinary sensitivity of the PCR process makes it highly vulnerable to contamination. ${ }^{81}$ As the National Research Council has made clear, "[a]ny procedure that uses PCR is susceptible to error caused by contamination leading to amplification of the wrong DNA." ${ }^{\prime 2}$ Contamination may occur from several sources, including handling in the field during collection, ${ }^{83}$ cross-contamination of samples in the laboratory, ${ }^{84}$ and carryover contamination (the contamination of evidence samples

78. TWGDAM, supra note 71 , at 26.

79. For a description of how PCR works, see supra notes 56-64 and accompanying text.

80. Quality Assurance Standards, supra note 67.

81. NRC, DNA TECHNOLOGY, supra note 53, at 65.

82. NRC, EVALUATION, supra note 53, at 71.

83. For instance, even dandruff contains DNA and may cause false results if somehow mixed with the evidence. Miguel Lorente et al., Dandruff as a Potential Source of DNA in Forensic Casework, 43 J. FORENSIC SCI. 901, 901-02 (1998).

84. The New York City Medical Examiner Facilities have documented small amounts of DNA on structural surfaces. Talya Toledano et al., An Assessment of DNA Contamination Risks in New York City Medical Examiner Facilities, 42 J. FoRENSIC SCI. 721, 721-24 (1997). 
or reaction solutions with PCR products from prior amplifications) ${ }^{85}$ Most relevant to the discovery rights at issue here, contamination may be caused by the kits themselves. Because of the sensitivity of the PCR process, the primers, which contain DNA, could contaminate the results. ${ }^{86}$ Without knowing the sequence of the primers, neither defense experts nor courts could determine if the effects of contamination by the primer sequence are present in the results. ${ }^{87}$

Lastly, knowledge of the primer sequences would help to explain a specific problem with the Profiler Plus kit that has arisen. In one study of the vWA locus, PE's Profiler Plus Kit and the Promega PowerPlex Kit produced inconsistent genotyping. ${ }^{88}$ To understand why the tests are producing different results, $\mathrm{PE}$ is sequencing the locus. ${ }^{89}$ Without access to the primer sequence used in the kit, defense experts are unable to perform similar testing.

\section{THE CURRENT DISCOVERY REGIME}

There is currently no nationally recognized right of access to the data underlying DNA kits. In the federal system and in the vast majority of states, discovery is controlled by statutes or court rules. ${ }^{90} \mathrm{Al}-$ though the statutory schemes are similar in structure, ${ }^{91}$ they vary

85. NRC, DNA TECHNOLOGY, supra note 53, at 66 ("The most serious problem is contamination of evidence samples and reactions solutions with PCR products from prior amplifications.")

86. Paul Smaglik, Legal Protests Prompt DNA Primer Release, 406 NATURE 336, 336

87. Id. Tom Mozer, a researcher working for Promega, contends that the chances of contamination are extremely low. Id.

88. Margaret C. Kline et al., Nonamplification of a vWA Allele, 43 J. ForENSIC SCI. 250, 250 (1998) (discussing the inconsistency in National Institute of Standards and Technology researcher documents, and indicating that PE "is aware of this problem and they are actively pursuing an explanation for this allelic dropout by sequencing the sample"); Sean Walsh, Commentary on Kline, MC, Jenkins B, Rogers S, Non-Amplification of a $v W A$ Allele, 43 J. FORENSIC SCI. 1103, 1103 (1998). PE admits the problem exists and claims it is caused by a flanking sequence mutation. Id. "Our laboratory has observed flanking sequence mutations in several STR loci, including vWA reported here, D16S539, and TPOX. Other laboratories have recently reported flanking sequence mutations at D13S317 and D7S820." Id. PE acknowledges that the problem will continue, but claims that it can be avoided by using PE products exclusively. Id.

89. Kline et al., supra note 88, at 250.

90. 4 Walter laFave et Al., Criminal Procedure 830 (1999). The development of the statutory scheme did not occur until fairly recently. As late as the 1970 s, a number of states still treated discovery as a common law subject. $I d$.

91. Id. at 830 . The typical discovery statute or court rule lays out the following: (1) a procedure by which the defense and prosecution can effectuate their discovery rights; (2) the items 
greatly in content. ${ }^{22}$ As a result, the status of discovery rights varies among jurisdictions. Most of these rules are quite restrictive of discovery in the criminal area. ${ }^{93}$ Discovery in criminal prosecutions traditionally has been extremely limited ${ }^{94}$ and remains far less robust than discovery in civil proceedings. ${ }^{95}$

There are a few common provisions that could be read to support discovery of the data at issue here, but they have been applied in a manner that limits their usefulness. Federal Rule of Criminal Procedure 16(a)(1)(D) ${ }^{96}$ and almost all state discovery provisions mandate the disclosure of scientific reports. ${ }^{97}$ Although the phrase "scientific report" could be interpreted to include any information relied upon, either explicitly or implicitly, in creating the final report, most jurisdictions have not interpreted the rule in this way. In fact, some states have specifically shielded from discovery "underlying documentation" used in preparing a final report. ${ }^{98}$ For example, the Ninth

that shall or may be disclosed by both sides; (3) the exemptions from disclosure based on either content or some other characteristic; (4) the circumstances under which the trial court may issue a protective order; (5) the continuing duty to disclose so that the items acquired after initial disclosure are automatically revealed to the other party; and (6) enforcement provisions. Id.

92. Id.

93. Hon. H. Lee Sarokin \& William E. Zuckerman, Presumed Innocent? Restrictions on Criminal Discovery in Federal Court Belie this Presumption, 43 RUTGERS L. REV. 1089, 1089 (1991).

94. William J. Brennan, Jr., The Criminal Prosecution: Sporting Event or Quest for Truth? A Progress Report, 68 WASH. U. L.Q. 1, 4 (1990) (describing as bleak the criminal discovery situation before Brady v. Maryland, 373 U.S. 83 (1963), and surmising that "the lack of access at that time to materials essential to the testing of the government's case and to the development of the defense must surely have resulted in some unjust convictions"); Sarokin \& Zuckerman, supra note 93, at 1092 (noting that the existence of formal provisions for discovery in federal criminal litigation is a relatively recent phenomenon).

95. Sarokin and Zuckerman have noted that

[i]t is an astonishing anomaly that in federal courts virtually unrestricted discovery is granted in civil cases, whereas discovery is severely limited in criminal matters. In other words, where money is involved, all parties receive all relevant information from their adversaries upon request; but where individual liberty is at stake, such information can be either withheld by the prosecutor or parceled out at a time when it produces the least benefit to the accused.

Sarokin \& Zuckerman, supra note 93, at 1089.

96. Rule 16(a)(1)(D) grants the defense discovery of the "results or reports of physical or mental examinations, and of scientific tests or experiments." FED. R. CRIM. P. 16(a)(1)(D).

97. 4 LAFAVE ET AL., supra note 90, at 860 . Some states continue to make disclosure of scientific reports discretionary. Id. at 861 .

98. E.g., United States v. Iglesias, 881 F.2d 1519, 1524 (9th Cir. 1989) (denying discovery of a chemist's $\log$ notes); Roberts v. State, 396 S.E.2d 81, 81 (Ga. Ct. App. 1990) (denying discovery of an expert's notes, work product, recordation of data, internal documents, or graphs). 
Circuit has made clear that log notes produced in the testing process are not discoverable as scientific reports. ${ }^{99}$ Thus, Rule 16(a)(1)(D) and its counterparts present an unsure avenue by which to pursue discovery of this evidence.

The other discovery rule that could be read to allow for discovery of the developmental validation data and primers is Federal Rule of Criminal Procedure 16(a)(1)(C). Rule 16(a)(1)(C) and the rules patterned after it allow discovery of documents and objects "which are material to the preparation of the defendant's defense." ${ }^{100}$ In jurisdictions in which documents are not discoverable as scientific reports, courts have held that they still may be discoverable under Rule 16(a)(1)(C). ${ }^{101}$ For example, in United States $v$. Yee, ${ }^{102}$ the court, relying on Rule 16(a)(1)(C), held discoverable laboratory matching criteria and standards, environmental insult tests, population data, and proficiency testing data held by the FBI. ${ }^{103}$ However, the application of Rule 16(a)(1)(C) is limited to those things within the government's control. It does not cover evidence held by third parties. ${ }^{104}$ Thus, as long as the kit makers decline to share their information with the crime labs using their kits, Rule 16(a)(1)(C) may not grant the defense discovery.

There is currently no reliable scheme in place that provides for the discovery of data underlying DNA kits. ${ }^{105}$ However, denying a defendant access to this data may violate the Constitution. If the underlying scientific data is not provided, and the evidence provided by the kits is admitted, the defendant's rights under the Compulsory Process, Confrontation, and Due Process Clauses are violated.

\footnotetext{
99. Iglesias, 881 F.2d at 1524.

100. FED. R. CRIM. P. 16(a)(1)(c).

101. See, e.g., United States v. Liquid Sugars, Inc., 158 F.R.D. 466, 470-75 (E.D. Cal. 1994) (noting that even when log notes are not discoverable as scientific reports, they may be discoverable under Rule 16(a)(1)(C), which provides that the government shall, upon request, permit the defendant "to inspect and copy or photograph books, papers, [and] documents ... which are [in the government's] possession ... . and [which are] material to the preparation of the defendant's defense").

102. 129 F.R.D. 629 (N.D. Ohio 1990).

103. Id. at 636 .

104. United States v. Armstrong, 621 F.2d 951, 954 (9th Cir. 1980).

105. Compare the rules for criminal discovery with Federal Rule of Civil Procedure 26(b)(4), which provides for far greater discovery of data underlying expert opinions. For a criticism of the current restrictive discovery rules and a proposal for new, more expansive rules, see Paul C. Giannelli, Criminal Discovery, Scientific Evidence, and DNA, 44 VAND. L. REV. 791, 821-25 (1991).
} 


\section{ARguments AgAinst EXPANDED CRIMINAL DisCOVERY}

\section{A. The Traditional Arguments Against Criminal Discovery}

The traditional arguments against criminal discovery are premised on the idea that the Bill of Rights's protections for the accused skew the adversarial system in the defendant's favor. The most succinct expression of this argument was made by Judge Hand:

Under our criminal procedure the accused has every advantage. While the prosecution is held rigidly to the charge, he need not disclose the barest outline of his defense. He is immune from question or comment on his silence; he cannot be convicted when there is the least fair doubt in the minds of any one of the twelve. Why in addition he should in advance have the whole evidence against him to pick over at his leisure, and make his defense, fairly or foully, I have never been able to see. ${ }^{106}$

Hand's first contention, that the defendant need not disclose "the barest outline of his defense," has become less compelling as states have moved toward allowing prosecutorial discovery. The expansion of prosecutorial discovery gained momentum in the $1970 \mathrm{~s}^{107}$ and currently a majority of states have discovery rules that provide the same rights of discovery to the prosecution as to the defense. ${ }^{108}$ Hand's second argument against criminal discovery relates to the defendant's right to remain silent. Hand obviously considered the Fifth Amendment a significant advantage to the defendant in the adversarial process. However, as numerous commentators have pointed out, police officers regularly obtain incriminating statements from criminal defendants during pretrial interrogations, despite Miranda warnings. ${ }^{109}$

Another commonly raised argument against liberal criminal discovery rests on the fear that criminal defendants will attempt either to intimidate witnesses or obtain perjured testimony that contradicts the

\footnotetext{
106. United States v. Garsson, 291 F. 646, 649 (S.D.N.Y. 1923).

107. Robert P. Mosteller, Discovery Against the Defense: Tilting the Adversarial Balance, 74 CAL. L. REV. 1567, 1569 (1986).

108. Id. at 1579. For example, Michigan Court Rule 6.201 provides that both the prosecution and the defense must disclose the names and addresses of lay and expert witnesses. Mark A. Esqueda, Note, Michigan Strives to Balance the Adversarial Process and Seek the Truth with its New Reciprocal Criminal Discovery Rule, 74 U. Det. MerCY L. REV. 317, 342 (1997).

109. E.g., Jean Montoya, A Theory of Compulsory Process Clause Discovery Rights, 70 IND. L.J. 845, 859-60 (1995).
} 
prosecution's case.$^{110}$ Regardless of this argument's merit in other contexts, its merit in the context of scientific evidence is certainly limited. The significance of witness intimidation is reduced where a witness's testimony is reproducible. If one expert backs out, the evidence could be tested anew by a braver soul. ${ }^{111}$ The possibility for perjury as to the content of scientific evidence is equally limited; as the ABA has noted, "it is virtually impossible for evidence or information of this kind to be distorted or misused because of its advance disclosure." ${ }^{112}$

\section{B. The Trade Secret/Innovation Argument}

A more compelling argument against liberal discovery of the scientific basis of DNA kit testing rests on the possibility that forced disclosure could result in less, or slower, innovation in forensic sciences in the future. The kit makers have implicitly relied on such a rationale in arguing that the data sought is protected from discovery as a trade secret. ${ }^{113}$ The trade secret privilege, like all intellectual property law, is based in part on the premise that protection of property is required to foster innovation. ${ }^{114}$ The trade secret privilege has been upheld in the context of DNA kit testing by a trial court in Arizona, ${ }^{115}$ among others.

The kit makers are certainly correct in emphasizing the role that private innovation played in the development of forensic DNA tech-

110. See State v. Tune, 98 A.2d 881, 884 (N.J. 1953) (denying the defendant access to his own confession). Tune was later overruled by State v. Johnson, 145 A.2d 313 (N.J. 1958).

111. Giannelli, supra note 105 , at 799 .

112. 1 GIANNELLI \& IMWINKELRIED, supra note 55, § 3-1, at 134 (citing A.B.A. ProJeCT on Standards for Criminal Justice, Standards Relating to Discovery and PROCEDURE Before TRIAL 66 (Approved Draft 1970) [hereinafter STANDARDS FOR CRIMINAL Justice]).

113. Abate, supra note 7, at B1; see also Defense Motion to Compel Third Party Discovery, People v. Hunt, No. SA034500, at 8 (Cal. Super. Ct. filed May 1, 2000) (noting that PE invoked the trade secret privilege in resisting a discovery request) (on file with the Duke Law Journal).

114. Kewanee Oil Co. v. Bicron Corp., 416 U.S. 470, 481 (1974) (articulating several policies behind laws that prohibit the misappropriation of trade secrets, including " $[\mathrm{t}]$ he maintenance of standards of commercial ethics and the encouragement of invention"). The encouragement of invention underlies not only trade secret law; it extends to justify all of intellectual property law. For example, the Copyright Clause provides Congress the power to regulate appropriation of "Writings and Discoveries" in order "[t]o promote the Progress of Science and useful Arts." U.S. CONST. art. I, § 8, cl. 8.

115. State v. Lynch, No. CR 98-11390, slip op. at 5 (Ariz. Super. Ct. Aug. 20, 1999) (noting that "[i]n a perfect world, one would suppose that every step, ingredient and method of manufacturing of devices, products, medicines and the like would be in the public domain"). 
nology. Lifecodes and Cellmark Laboratories, both private corporations, began forensic testing in 1987, a year before the FBI opened the first publicly operated DNA typing lab. ${ }^{116}$ The first DNA evidence introduced in court was the result of a Lifecodes Corporation test, ${ }^{117}$ and the first death penalty conviction involving DNA evidence was achieved using DNA evidence produced by Cellmark Diagnostics. ${ }^{118}$ The FBI's decision to open a DNA laboratory was based in part upon the desire to reduce the role of corporations in forensic testing. ${ }^{119}$ Despite the opening of public laboratories, private corporations remained central to innovation in forensic DNA technology. ${ }^{120}$ The opening of public laboratories ensured that most actual analysis would be conducted by public employees, but the equipment and kits used by state laboratories continue to be produced by corporations.

Nevertheless, the appropriateness of applying the trade secret privilege to kit makers is complicated by the fact that the privilege is far more developed in civil litigation than it is in criminal law. ${ }^{121}$ The discrepancy is best explained by the history of trade secret misappropriation law, which provides the forum in which parties are most likely to claim a trade secret privilege. Until recently, trade secret law provided a remedy for trade secret misappropriation only through civil litigation. ${ }^{122}$

116. Janet C. Hoeffel, Note, The Dark Side of DNA Profiling: Unreliable Scientific Evidence Meets the Criminal Defendant, 42 STAN. L. REV. 465, 471 nn.29-31 (1990).

117. Id. at $471 \mathrm{n} .29$. The Lifecodes testing method was also the first DNA typing method to be approved by an appellate court. See Andrews v. State, 533 So. 2d 841, 849 (Fla. Dist. Ct. App. 1988) (finding that "scientific testimony indicates acceptance of the [Lifecodes] testing procedures").

118. Hoeffel, supra note 116, at 471 n.30.

119. Id. at $471 \mathrm{n} .31$.

120. The large part played by private corporations in forensic DNA testing is not unique to the United States. The Council of Europe warns "against monopolies by certain biomedical firms or police laboratories which at present seem to dominate the market." COMM. OF Ministers of THE COUNCIL OF EuR., THE USE of ANALYSIS OF DEOXYRIBONUClEIC ACID (DNA) Within the Framework of THE CRiminal Justice System 33 (1993). The Canadian police contract out analysis of DNA gathered at crime scenes. RCMP Hires Private Lab to Test DNA After Criticism by Auditor General, CANADIAN PRESS, Jan. 3, 2001 (describing the two-year, $\$ 2$ million contract to Maxxam following an eight-month, worldwide search for a private sector partner).

121. Kenneth Rosenblatt, Criminal Law and the Information Age: Protecting Trade Secrets from Disclosure in Criminal Cases, COMPUTER LAW., Jan. 1991, at 15.

122. In fact, trade secret law was entirely common law until the emergence of the Uniform Trade Secrets Act in 1979. Susan V. Metcalfe, Comment, Protecting Trade Secrets: Is the Rem- 
In contrast, the boundaries of the trade secret privilege in criminal cases remain less clear, largely because the privilege rarely arises in the criminal context. ${ }^{123}$ Although more than half of the states now protect trade secrets through criminal statutes, state prosecutors rarely use them. ${ }^{124}$ Nor has the Economic Espionage Act, ${ }^{125}$ the federal criminal trade secret law, produced a barrage of cases; prosecutions under the Act have been few because Attorney General Janet Reno required that charges under the Act not be brought without her personal approval or the approval of her deputy until October $2001 .^{126}$ The Federal Rules of Criminal Procedure also provide limited guidance, allowing only that: "Upon a sufficient showing the court may at any time order that the discovery or inspection be denied, restricted, or deferred, or make such other order as is appropriate." ${ }^{12}$

The role of the trade secret privilege in criminal cases has been addressed by at least one state legislature. Under California evidence law, the trade secret privilege does apply to criminal cases. ${ }^{128}$ However, the privilege is not absolute: "No evidence, however, shall be excluded during a criminal proceeding pursuant to this section if it

edy Worse than the Wrong?, 104 Dick. L. REV. 503, 506 (2000). The Uniform Trade Secrets Act has been adopted by forty-four states and the District of Columbia. Id.

123. Rosenblatt, supra note 121, at 16 ("The poor fit between criminal law and trade secret law has not been evident until recently ....").

124. Michael Coblenz, Intellectual Property Crimes, 9 ALB. L.J. SCI. \& TECH. 235, 286 (1999) (explaining that federal legislation was enacted to "fill this gap in criminal prosecution").

125. 18 U.S.C. $\S \S 1831-1839$ (1994 \& Supp. V 1999). Congress became motivated to intervene in trade secret protection by claims that foreign governments had tried to appropriate information developed and controlled by United States companies. Joseph F. Savage et al., Trade Secrets: Conflicting Views of the Economic Espionage Act, CRIM. JUST., Fall 2000, at 10. Congress was further motivated by studies revealing that nearly $\$ 24$ billion worth of corporate intellectual property was stolen each year. United States v. Hsu, 155 F.3d 189, 194 (3rd Cir. 1998). It has been claimed that intellectual property theft, both foreign and domestic, cost American companies over $\$ 300$ billion in 1997. Carol Noonan \& Jeffery Raskin, Intellectual Property Crimes, 38 AM. CRIM. L. REV. 971, 973 (2001).

126. Hsu, $155 \mathrm{~F} .3 \mathrm{~d}$ at $194 \mathrm{n} .4$ (noting that only five prosecutions were publicly announced in the first eighteen months following enactment of the Act). In the Hsu case, the Third Circuit Court of Appeals overturned a lower court finding that the defendant's constitutional right to cross-examination and a fair trial would be violated were he not granted access to claimed trade secrets. Id. at 197. Because the defendant was not charged with the completed crime of trade secret misappropriation, but was instead charged with conspiracy and attempt to steal, the trade secrets themselves were not material to the government's case. Id. at 203. Instead, the government needed only to prove that the defendant sought to acquire information that he believed was a trade secret, regardless of whether the information actually qualified as such. $I d$.

127. FED. R. CRIM. P. 16(d)(1).

128. CAL. EvID. CODE $\S \S 1061-1063$ (West 1995). 
would conceal a fraud, work an injustice, or deprive the People or the defendant of a fair trial." ${ }^{129}$

Assuming for the moment that PE is correct in asserting that the developmental data and primer sequences are trade secrets, a balancing of equities makes clear that the data should be revealed at least to the defendant and his expert witnesses. Here, the denial of access to the claimed trade secrets is highly prejudicial; in fact, it severely infringes on the defendant's constitutional rights. ${ }^{130}$ Moreover, although it may be true that the dissemination of the information could damage kit makers economically, it also must be noted that kit makers are under a scientific obligation to release this information for peer review. The TWGDAM guidelines state: "It is essential that the results of the developmental validation studies be shared as soon as possible with the scientific community through presentations at scientific/professional meetings. It is imperative that details of these studies be available for peer review through timely publications in scientific journals." 131

Lastly, protective orders are available to limit public access to the information. Protective orders are, of course, unsatisfying to both parties. PE and other kit makers fear that they will be violated. ${ }^{132}$ Defense lawyers argue that secrecy impedes understanding of the tests and contravenes scientific principles of peer review. ${ }^{133}$ As one commentator put it, "If scientific evidence is not yet ready for both scientific scrutiny and public re-evaluation by others, it is not yet ready for court." $" 134$

In the end, the question becomes: Do we want to encourage technological innovation at the expense of the constitutional rights of defendants? As importantly, does forensic technology increase the ability of the system to find truth where the evidence cannot be effec-

129. Id. § 1062(a).

130. See infra Part IV.

131. TWGDAM, supra note 71 , at 26.

132. Companies may not want to risk exposure, based upon an instance in which protected information was turned over by PE and later published by the defense's expert witness. Abate, supra note 7, at B1.

133. Thompson, supra note 1 , at 100 (arguing that "[t]here is no excuse for secrecy concerning the raw data" because "[a]ccording to long-standing and wise scientific tradition, the data underlying an important scientific conclusion must be freely available, so that others can evaluate the results and publish their own findings").

134. Id. 
tively challenged by the defense? Even the most discerning forensic technology will sometimes produce inaccurate results. If the accuracy of forensic technology is not open to effective questioning, the technology will achieve convictions without ensuring justice.

\section{The Argument that the Burden of Collecting the Information Is Too Great}

At least one trial court, People v. Bertsch \& Hronis, has allowed the prosecution to use PE kit results despite PE's refusal to disclose the underlying data because it believed that compliance with the defendant's subpoena would be unduly burdensome. ${ }^{135}$ The court agreed with PE that "the burden on the third party... outweighs substantially the alleged demonstrated need as set forth." 136 The court felt that the defendant's need was not substantial, and certainly did not rise to the level of a constitutional defect, even though the defendant had no access to the primer sequences and only partial access to developmental data. ${ }^{137}$ The court did not indicate how much developmental data was provided. ${ }^{138}$

Not only did the court underestimate the burden that lack of access would impose on the defendant, ${ }^{139}$ it also overestimated the burden that production of the data would create for PE. The court said: "it is a significant burden involving several people, four people over several weeks." ${ }^{140}$ While this may be true, PE should have anticipated such a request and better organized its data. Even though PE has not yet published its developmental data, the PE "Users Manual" that it distributes with its kits promises peer review publication of the developmental data. ${ }^{141}$ Furthermore, both TWGDAM and DAB Guidelines call for publication of developmental validation. Practically

135. Reps.' Daily Tr. of Proceedings, People v. Bertsch \& Hronis, No. 94F07295, at 20,377 (Cal. Super. Ct. Oct. 20, 1999).

136. Id.

137. Id. at 20,370 .

138. Id.

139. I would argue that the defendant's need was underestimated by the court; not only is access to the data underlying the kits highly relevant for challenging their reliability, denial of access to that data impinges upon the defendant's constitutional rights, an argument explored further in Part IV.

140. Bertsch \& Hronis, Reps.' Tr. at 20,376.

141. Defense Mot. to Compel Third Party Disc., People v. Hunt, No. SA034500, at 5 (Cal. Super. Ct. filed May 1, 2000) (on file with the Duke Law Journal). 
speaking, one must question the burden on an enormously wealthy company like PE of hiring a few people for a few weeks to collect and organize the data.

\section{The Withdrawal from the Market Argument}

In Michigan, where a panel of three district court judges recently considered the admissibility of Profiler Plus test results, law enforcement openly worried that a discovery order would lead PE and other biotechnology companies to withdraw their products from the forensic science market. ${ }^{142}$ Such fears are reinforced by the fact that forensic testing kits and equipment account for only ten percent of the sales of Applied Biosystems (the division of PE that markets forensic DNA kits). ${ }^{143}$

There are indications, however, that law enforcement would remain a profitable market for PE. Although revelation of the primer sequences and developmental validation data creates the opportunity for labs to use PE technology without purchasing a kit, many labs will continue to use kits because of the kits' efficiency. ${ }^{144}$ It is possible to create one or two primers by hand, ${ }^{145}$ but forensic scientists at overburdened labs appreciate the shortcut that pre-prepared primers provide. ${ }^{146}$

Even if the forensic market remains profitable, corporations may prefer to abandon that market if revelation of the data would severely harm their competitiveness in other life science industries. In the end, however, the best indication of an industry's ability to withstand

142. Guthrie, supra note 10 , at $\mathrm{C} 1$. Although the withdrawal of DNA kit makers from the market appears to be a price defense lawyers are willing to pay, the exculpatory possibilities of DNA evidence ensure that the defense community also has an interest in the continued possibility of DNA testing. On forensic DNA testing and exculpation, see Walter F. Rowe, Commentary to EDWARD CONNORS ET AL., CONVICTED BY JURIES, EXONERATED BY SCIENCE: CASE Studies IN THE Use of DNA Evidence to Establish InNocence AfTer Trial, at xvii-xviii (1996) (noting twenty-eight cases in which DNA established innocence after trial).

143. Guthrie, supra note 10, at C1.

144. Id.

145. Smaglik, supra note 86 , at 336 .

146. For a description of the backlog at most DNA labs, see GREG W. STEADMAN, SURVEY OF DNA CRIME LABORATORIES, 1998, at 1 (2000) (noting that at the end of 1997, sixty-nine percent of DNA labs had a backlog of 6800 known and unknown subject cases and 287,000 convicted offender samples). The time saved by using DNA kits, or one DNA kit over another, is extremely important to the labs that buy kits. See Doug Guthrie, DNA Testing Faces a Trial of Its Own, GRAND RAPIDS PRESS, Aug. 31, 2000, at A1 (describing how the Michigan State Police labs hoped to cut back on a persistent two-month backlog in cases by adopting new PE kits). 
revelation of proprietary information is provided by the industry itself. Promega, the other provider of STR multiplex kits, already has indicated that it is willing to sacrifice secrecy for access to the forensic market. ${ }^{147}$ If a particular corporation feels it cannot afford to reveal the information, it seems highly likely that another will emerge to take its place.

\section{CONSTITUTIONAL IMPLICATIONS OF THE LACK OF DISCOVERY OF DEVElopmental VALIDATION DATA AND PRIMER SEQUENCES}

The Supreme Court has noted that " $[\mathrm{t}]$ here is no general constitutional right to discovery in a criminal case." ${ }^{148}$ Unfortunately for the clarity of the Court's holdings on discovery and constitutionality, the statement (1) fails to accurately describe the Court's own holdings under the Compulsory Process, Confrontation, and Due Process Clauses; and (2) undercuts the values embodied in these three clauses, particularly as those values relate to the reliability of scientific evidence. Not only is there a constitutional right to discovery, that constitutional right applies to the data that supposedly demonstrates the scientific reliability of DNA evidence used against defendants. The Constitution requires that test results not be admitted unless defendants are given access to the scientific data alleged to establish the kits' reliability.

\section{A. Compulsory Process}

To date, no trial or appellate court has considered whether admitting DNA evidence against a defendant who lacks access to the data underlying the DNA testing kit violates the Compulsory Process Clause. However, as the following discussion demonstrates, admitting DNA evidence in these circumstances violates the dictates of the Compulsory Process Clause and undercuts the values it represents.

The Compulsory Process Clause of the Sixth Amendment establishes that "in all criminal prosecutions, the accused shall enjoy the right ... to have compulsory process for obtaining witnesses in his favor." "At a minimum, compulsory process means "that criminal de-

147. Smaglik, supra note 86 , at 336 .

148. Weatherford v. Bursey, 429 U.S. 545, 559 (1977).

149. U.S. CONST. amend. VI. The Compulsory Process Clause is applicable to the states through the Due Process Clause of the Fourteenth Amendment. Washington v. Texas, 388 U.S. 14, 17-19 (1967). 
fendants have the right to the government's assistance in compelling the attendance of favorable witnesses at trial and the right to put before a jury evidence that might influence the determination of guilt." ${ }^{250}$ There are two issues here. First, to what degree, if any, does the Compulsory Process Clause include a right of discovery? Second, if such a discovery right exists, is it applicable to developmental validation and primer sequences held by private corporations?

The two cases that deal most directly with the rights of discovery created by compulsory process are United States v. Nixon ${ }^{151}$ and United States v. Burr. ${ }^{152}$ In Nixon, the Court unanimously upheld an order requiring President Nixon to produce tapes of his personal conversations with the Watergate defendants. The defendants' right of discovery was grounded at least partly in the Compulsory Process Clause: "The right to the production of all evidence at a criminal trial similarly has constitutional dimensions. The Sixth Amendment explicitly confers upon every defendant in a criminal trial the right ... 'to have compulsory process for obtaining witnesses in his favor.",153

The second significant case is United States v. Burr. ${ }^{154}$ Burr was on trial for treason and sought discovery of a letter from General Wilkinson to President Jefferson. Burr wanted the letter because President Jefferson claimed to rely upon it when he announced to Congress that he believed Burr to be guilty of treason. ${ }^{155}$ President Jefferson's main objection to the subpoena duces tecum was that it arrived prematurely, before the grand jury indicted Burr. ${ }^{156}$ In rejecting this argument, Marshall explicitly relied upon the Compulsory Process Clause as a source of pretrial discovery:

Upon immemorial usage, then, and upon what is deemed a sound construction of the constitution and law of the land, the court is of

150. Pennsylvania v. Ritchie, 480 U.S. 39, 56 (1987) (plurality opinion). For a detailed discussion of the limits of Confrontation Clause protections, see Peter Westen, Confrontation and Compulsory Process: A Unified Theory of Evidence for Criminal Cases, 91 HARV. L. REV. 567, 567 (1978) (examining the parallels between compulsory process and confrontation).

151. 418 U.S. 683 (1974).

152. 25 F. Cas. 30 (C.C.D. Va. 1807) (No. 14692D).

153. Nixon, 418 U.S. at 711.

154. Although Burr emerged from a federal court in Virginia, and not the Supreme Court, it was written by the future Chief Justice Marshall and has been cited in a later Supreme Court opinion as "the first and most celebrated analysis" of the Compulsory Process Clause. Ritchie, 480 U.S. at 55.

155. Burr, 25 F. Cas. at 32.

156. Id. 
[the] opinion that any person charged with a crime in the courts of the United States has a right, before as well as after indictment, to the process of the court to compel the attendance of his witnesses. 157

In holding the subpoena valid, Marshall also made clear that the word "witnesses" includes written materials. ${ }^{158} \mathrm{He}$ rejected any distinction between people and things under the Compulsory Process Clause. ${ }^{159}$

The question remains whether the Compulsory Process Clause creates a right of discovery applicable to the data and developmental validation studies underlying DNA kits. In United States $v$. Nixon, the Court explained that parties in criminal trials who move for a subpoena duces tecum ${ }^{160}$

157. Id. at 33. The Compulsory Process Clause is not the only right for which the courts have recognized pretrial implications. In Powell v. Alabama, 287 U.S. 45 (1932), the Court emphasized the importance of pretrial preparation, describing the time from arraignment until the beginning of trial as perhaps the "most critical period of the proceedings against these defendants." Id. at 57. Because the defendants in Powell were without counsel during the pretrial period defined by the Court, their Sixth Amendment right to counsel was abrogated. $I d$.

158. Burr, 25 F. Cas. at 34.

159. See id. at 35 (stating that the only difference between a subpoena and a subpoena duces tecum was that a witness was required to bring a piece of paper). Although the 1987 case of Pennsylvania v. Ritchie limits the reach of the Compulsory Process Clause, the restrictions announced do not apply to the type of discovery at issue here: discovery of data held by a third party. In Ritchie, the Court noted that it had "never squarely held that the Compulsory Process Clause guarantees the right to discover the identity of witnesses, or to require the government to produce exculpatory evidence." 480 U.S. at 56. However, the Compulsory Process Clause may still be used to subpoena information from parties that are not governmental. Even the Court's announcement that the Compulsory Process Clause does not apply to information held by the government or to witnesses' names is of less-than-stellar precedential value. First, the opinion was decided by a plurality, not a majority. Second, the Court neglected to apply its new rule to the facts of the case, choosing instead to decide the case on other grounds. Id. ("Because the applicability of the Sixth Amendment to this type of case is unsettled, and because our Fourteenth Amendment precedents addressing the fundamental fairness of trials establish a clear framework for review, we adopt a due process analysis for purposes of this case."). Indeed, it has been noted that the Compulsory Process Clause is uniquely able to provide for discovery of information not produced by government investigation. Montoya, supra note 109, at 875 (suggesting that the Compulsory Process Clause appropriately governs a defendant's access to raw evidence, whereas the Due Process Clause ought to govern a defendant's access to information produced by the government's factfinding efforts).

160. The federal standard for a subpoena duces tecum is set out in Rule 17(c), which reads:

A subpoena may also command the person to whom it is directed to produce the books, papers, documents or other objects designated therein. The court on motion made promptly may quash or modify the subpoena if compliance would be unreasonable or oppressive. The court may direct that books, papers, documents or objects designated in the subpoena be produced before the court at a time prior to the trial or prior to the time when they are to be offered in evidence and may upon their produc- 
"must clear three hurdles: (1) relevancy; (2) admissibility; (3) specificity."

Here, the information is undoubtedly relevant. The prosecution, through expert testimony, will want to show that the kits provide reliable and accurate information, and defendants will want to show, through the developmental validation study and primers, that the kits either are not generally reliable or failed to provide reliable information in a particular case. ${ }^{162}$

Next, the movant must show that evidence of the developmental validity study and primers is admissible. This information is almost certainly admissible during a pretrial hearing to determine the admissibility of DNA evidence. Under Federal Rule of Evidence 104(a), a judge's admission of foundational or preliminary facts is not bound by rules of evidence except with respect to privileges. ${ }^{163}$ Courts have uniformly held this rule to override the general applicability to preliminary facts of exclusionary rules such as hearsay. ${ }^{164}$ The admissibility of

tion permit the books, papers, documents or objects or portions thereof to be inspected by the parties and their attorneys.

FED. R. CRIM. P. 17(c).

161. 418 U.S. 683,700 (1974). This was the court's summation of a more detailed listing of requirements, which demands

(1) that the documents are evidentiary and relevant; (2) that they are not otherwise procurable reasonably in advance of trial by exercise of due diligence; (3) that the party cannot properly prepare for trial without such production and inspection in advance of trial and that the failure to obtain such inspection may tend unreasonably to delay the trial; and (4) that the application is made in good faith and is not intended as a general "fishing expedition."

Id. at 699-700.

162. For an explanation of the relevance of developmental data and primer sequences to the reliability of DNA kits specifically, see supra notes 67-89 and accompanying text. For an explanation of the relevance of validity studies to scientific techniques generally, see Edward J. Imwinkelried, Coming to Grips with Scientific Research in Daubert's "Brave New World": The Courts' Need to Appreciate the Evidentiary Differences Between Validity and Proficiency Studies, 61 BROOK. L. REV. 1247, 1257-60 (1995). Professor Imwinkelried explains that scientific witnesses testify using a syllogism. Their major premise relates to the probative value of the technology. Id. at 1257 . For example, an expert's testimony may be that when the DNA fragments on two autoradiograms are of the same length and in the same position, the match indicates that the fragments may come from the same source, or at least share genetic markers. Id. The minor premise will be that the similarity of the two autoradiograms in the case at hand show that the DNA samples tested may come from the same source. Id. A validity study is relevant to the major premise in that the study would show whether the autoradiograms actually indicate a possible "match." Id. at 1258.

163. FED. R. EVID. 104(a).

164. Imwinkelried, supra note 162 , at 1260 . 
validity studies at trial is not quite as clear-cut, ${ }^{165}$ but the great probative value of this evidence makes it likely that courts will find it admissible. The most important use of this evidence may very well be during the pretrial hearing, where the evidence will be used to determine whether the jury ever even hears the results of scientific testing. ${ }^{166}$ Its admissibility before trial surely satisfies the requirements of Nixon, which interprets the Compulsory Process Clause to be concerned primarily with the effective functioning of the adversarial system.

The third requirement relates to the specificity of the request. The request for discovery of developmental validation and primer sequences is highly specific. Despite PE's protestations to the contrary, the data is both discrete and of a type regularly produced during a kit's validation. ${ }^{167}$

Lastly, an understanding of the Compulsory Process Clause that mandates disclosure of the data makes sense in light of the policy goals identified in cases interpreting the clause. The Supreme Court has written that " $[\mathrm{t}]$ he right to offer the testimony of witnesses, and to compel their attendance, if necessary, is in plain terms the right to present a defense ... to the jury so it may decide where the truth lies. ${ }^{168}$ Here the Court identified two interrelated themes in Compulsory Process Clause jurisprudence: adversariness and truth seeking. Increased access to the data underlying DNA kits serves both those goals. It enables defendants to challenge the evidence against them, and it enables the court to understand better the value of DNA evidence.

165. Id. at 1260-67. Imwinkelried argues that a rigid application of the hearsay doctrine might prevent the admissibility of a validity study in Daubert jurisdictions. Id. at 1265 . However, he also notes that no court has ever accepted this argument and that there are strong policy objections to doing so. Id. at 1283-84.

166. In both Frye and Daubert jurisdictions, reliability, which validity studies demonstrate, is used to determine the admissibility of scientific evidence. See supra notes 19-50, 67-78 and accompanying text.

167. DAB guideline 4.1.5.2 requires that developmental validation studies be shared as soon as possible with the scientific community. Quality Assurance Standards, supra note 67. Guideline 4.1.4 requires the same of the primers. Id. The ability to share the information with the scientific community surely translates into the ability to share the information with the courts.

168. Washington v. Texas, 388 U.S. 14, 19 (1967). 


\section{B. Confrontation Clause}

Like the Compulsory Process Clause, the Confrontation Clause has been noticeably absent from any discussion of the discoverability of kit data. Even though this absence is perhaps more understandable, because the Supreme Court recently has limited sharply the Clause's application to pretrial discovery, there is a plausible argument that even under the Court's narrowed understanding of the Confrontation Clause, the conflict at issue here constitutes an infringement of defendants' Confrontation Clause rights. Furthermore, the values embodied by the Confrontation Clause are as much at risk in denial of discovery as are the values embodied in the Compulsory Process Clause.

The Supreme Court has not been generous to criminal defendants in interpreting the mandates of the Confrontation Clause. Whereas the Compulsory Process Clause has been read to include pretrial discovery rights, the Court has described the Confrontation Clause as follows:

The opinions of this Court show that the right of confrontation is a trial right, designed to prevent improper restrictions on the types of questions that defense counsel may ask during cross examination. The ability to question adverse witnesses, however, does not include the power to require the pretrial disclosure of any and all information that might be useful in contradicting unfavorable testimony. ${ }^{169}$

In so holding, the Ritchie Court's plurality opinion made clear that the Confrontation Clause is "normally" satisfied so long as "defense counsel receives wide latitude at trial to question witnesses."

The above formulation of the Confrontation Clause raises the question of which cases are "normal." As Justice Blackmun noted in his concurrence, the plurality's decision to divorce Confrontation Clause rights from discovery rights amounts to a dismissal of any inquiry into "the effectiveness of the cross-examination" and renders confrontation rights, at least in some cases, an "empty formality." "171 The plurality's understanding of the Confrontation Clause creates the

169. Pennsylvania v. Ritchie, 480 U.S. 39, 52-53 (1987) (Powell, J., plurality opinion).

170. Id. at 53 .

171. Id. at 62 (Blackmun, J., concurring). 
greatest obstacle to effective cross-examination of expert witnesses. ${ }^{172}$ The complexity of many types of expert testimony, such as testimony on DNA testing, makes pretrial preparation imperative to effective cross-examination. ${ }^{173}$ Forensic scientists agree. According to Douglas Lucas, director of the Canadian Centre for Forensic Sciences, "If cross-examination is to be the only way to discover misleading or inadequate testimony by forensic scientists, then too much is being expected from it." "174 The extreme difficulty of effectively crossexamining an expert witness without pretrial preparation and discovery raises the issue of whether cross-examination of experts raises "normal" Confrontation Clause issues within the meaning of the Ritchie Court's plurality opinion.

Also, refusing defendants access to the scientific bases of evidence used against them contravenes fundamental Confrontation Clause values. The Confrontation Clause values with which the Supreme Court most consistently has concerned itself are the reliability of the evidence presented and the jury's ability to evaluate the strength of that evidence. ${ }^{175}$ These values are clearly set out in the Supreme Court's cases on hearsay. In Ohio v. Roberts ${ }^{176}$ the Court explained that the Confrontation Clause allows for the admission of an out-of-court statement by an unavailable declarant only if the state-

172. Paul C. Giannelli, Expert Testimony and the Confrontation Clause, 22 CAP. U. L. REV. 45, 62-63 (1993) ("Unfortunately, the Court failed to appreciate the problems associated with applying [its Confrontation Clause] standard to experts. The cross-examination of an expert 'poses a formidable task; it is the rare attorney who knows as much as the expert."') (quoting United States v. Wilson, 361 F. Supp. 510, 513 (D. Md. 1973)); Andrew Taslitz, Catharsis, the Confrontation Clause, and Expert Testimony, 22 CAP. U. L. REV. 103, 120 (1993) ("[L]awyers will be ill-equipped even to bring procedural flaws to a jury's attention absent extensive discovery that is often not available....").

173. StANDARDS FOR CRIMINAL JUSTICE, supra note 112, at 66 ("The need for full and fair disclosure is especially apparent with respect to scientific proof and the testimony of experts. This sort of evidence is practically impossible for the adversary to test or rebut at trial without an advance opportunity to examine it closely.").

174. Giannelli, supra note 172, at 63 (quoting Douglas M. Lucas, The Ethical Responsibilities of the Forensic Scientist: Exploring the Limits, 34 J. FORENSIC SCI. 719, 724 (1989)). Lucas is the director of The Centre of Forensic Sciences, Ministry of the Solicitor General, Toronto, Ontario. Lucas, supra, at 719 n.1.

175. Taslitz, supra note 172, at 122. Professor Taslitz also describes two other values of Confrontation Clause case law that would be promoted by increased discovery: (1) controlling government misconduct and (2) furthering catharsis, the process by which parties "vent their feelings before a group of average citizens who will understand the justice of the parties' position," and the community is assured that "order prevails and that justice is being done." Id. at 122, 126.

176. 448 U.S. 56 (1980). 
ment contains "indicia of reliability." that the Confrontation Clause is concerned with " afford[ing] the trier of fact a satisfactory basis for evaluating the truth of the prior statement." "178 The Court summed up its concern with both the reliability of the evidence presented and the jury's ability to evaluate that evidence in Greene v. McElroy: "[T] ernment's case must be disclosed to the individual so that he has an opportunity to show that it is untrue."179

Would the values described above be served by allowing defendants discovery of data underlying DNA kit results? Access to developmental data and primer sequences allows defendants to challenge the reliability of the kit results by, among other things: (1) questioning whether the kits were validated appropriately, (2) showing that the kits are prone to certain types of errors, and (3) looking for the effects of contamination in the PCR process. ${ }^{180}$ Moreover, the defense would be able to provide the jury with more information on the quality of the DNA evidence provided to it, thus enhancing the factfinding process.

\section{Due Process}

The constitutional clause most frequently discussed by courts in evaluating defense subpoenas for information held by private corporations is the Due Process Clause. In State v. Pfenning, ${ }^{181}$ for example, the trial court excluded the results of PowerPlex, Profiler Plus, and Cofiler where neither the defense nor the scientific community at large had access to validation data, stating "the manufacturer's proprietary concerns ... can not [sic] trump Defendant's right to a fair trial." ${ }^{182}$ Other trial courts have disagreed with the Pfenning court, holding that lack of access to the data does not raise any due process

177. Id. at 66 ("In sum, when a hearsay declarant is not present for cross-examination at trial, the Confrontation Clause normally requires a showing that [the declarant] is unavailable. Even then, his statement is admissible only if it bears adequate "indicia of reliability."'); see also Maryland v. Craig, 497 U.S. 836, 845 (1990) ("The central concern of the Confrontation Clause is to ensure the reliability of the evidence against a criminal defendant by subjecting it to rigorous testing in the context of an adversary proceeding before the trier of fact.").

178. Roberts, 448 U.S. at 65 (quoting California v. Green, 399 U.S. 149, 161 (1970)).

179. 360 U.S. 474, 496 (1959).

180. See supra Part I.

181. No. 57-4-96 (Vt. Dist. Ct. Apr. 6, 2000).

182. Id., slip op. at 52 . 
issues. In State v. Dishmon, ${ }^{183}$ the trial court found that PE's refusal to divulge primer sequences and developmental validation data did not violate the defendant's constitutional rights because the defendant "suffer[ed] no known harm by not having it." Dishmon court and others misunderstood the contours of the Due Process Clause.

In Brady v. Maryland, ${ }^{185}$ the Supreme Court held that the Due Process Clause of the Fourteenth Amendment requires the prosecutor to disclose evidence where the evidence is favorable to the defendant and "material either to guilt or to punishment, irrespective of the good faith or bad faith of the prosecution."

On first glance, Brady may appear to provide for a prosecutorial duty to disclose relevant evidence only where it is in the prosecutor's possession; that is, Brady seems not to apply to information held by third parties. However, in Kyles v. Whitley, ${ }^{187}$ the Supreme Court reversed a capital murder conviction for failure to disclose evidence even though that evidence was not in the possession of the prosecutor. ${ }^{188}$ The exculpatory evidence in question in Kyles was in the possession of the police. Instead of simply extending the Brady guarantee of disclosure to include information held by police officers, the Court went further:

[T]he individual prosecutor has a duty to learn of any favorable evidence known to the others acting on the government's behalf in the case, including the police. But whether the prosecutor succeeds or fails in meeting this obligation (whether, that is, a failure to disclose is in good faith or bad faith), the prosecution's responsibility for failing to disclose known, favorable evidence rising to a material level of importance is inescapable. ${ }^{189}$

Under Kyles, the first question of a Brady analysis becomes: is the holder of the information requested by the defense "acting on the government's behalf in the case?"

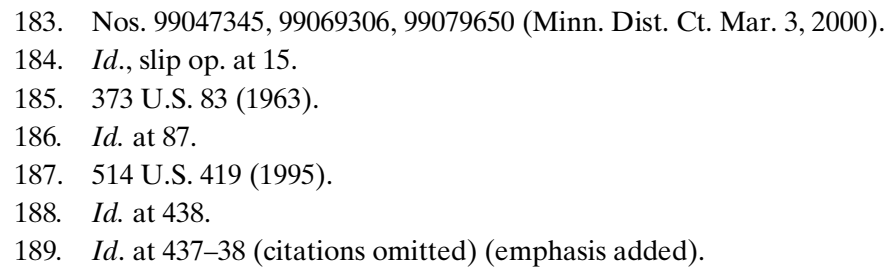


The question cannot be answered without a brief review of the history of development of DNA kits. When Congress authorized the creation of a National DNA Database in 1994, the FBI felt that the DNA testing methods then available were not sufficiently sophisticated to form the basis of a national standard. ${ }^{190}$ Dr. Budowle, the director of the Forensic Science Research and Training Center at the FBI Academy, has testified that he believed a multiplex PCR-based system would be the best system for national use. ${ }^{191}$ In 1994, the only multiplex systems available were triplex systems that he found to be inadequate. ${ }^{192}$ As a result, he decided to find a manufacturer that was willing to work with the FBI to develop a more complex multiplex system than those in existence at the time. ${ }^{193} \mathrm{He}$ felt only two companies were capable of developing an appropriate DNA typing system: PE and Promega. ${ }^{194}$ Dr. Budowle chose to talk to PE first because the FBI and PE had worked together in the past, and PE kits already were used by the FBI and other state crime laboratories. ${ }^{195}$

$\mathrm{PE}$ and the FBI together developed the new system over several years and through several phases. ${ }^{196}$ The first step required the development of the primer sequences to be used in PCR. ${ }^{197}$ The second and third steps involved developmental and forensic validation. ${ }^{198}$ During these stages, PE worked closely with the FBI and a group of laboratories chosen by Dr. Budowle. ${ }^{199}$ The laboratories tested early versions of the multiplex kit and reported the results of those tests to PE. ${ }^{200}$ In

190. People v. Shreck, No. 98CR2475, slip op. at 13 (Colo. Dist. Ct. 2000), available at http:// www.scientific.org/distribution/archive/Shreck.doc (on file with the Duke Law Journal), vacated by 22 P.3d 68 (Colo. 2001).

191. Id. Multiplexing uses PCR to duplicate more than one area of interest at a time. A different set of primers is used for each DNA segment to be duplicated. Multiplexing is significantly superior to monoplex STR systems. First, when thirteen loci are used, as in the test eventually developed by PE, the discriminatory power of the test equals that of a method using four or more RFLP loci. Dishmon, slip op. at 15. Second, the test can be completed in as little as three days, compared to three weeks for RFLP testing. Id.

192. Shreck, slip op. at 13.

193. Id.

194. Id.

195. Id.

196. Id.

197. Id.

198. Id.

199. Id.

200. Id. 
1998, the results of the collaboration, the Profiler Plus and Cofiler kits, went on the market. ${ }^{201}$

Any claim that PE developed its multiplex kits in an entirely private sphere, independent of government involvement, is disproved by the history of its development. The government, in the form of FBI scientist Dr. Budowle, both suggested the form that the kits should take and participated extensively in their development. Nonetheless, this history does not entirely support a finding that the kit makers work "on behalf of the government." Undoubtedly PE acted on its own behalf as well. Moreover, other kit makers, such as Promega, may have no such ties to the government.

As a result, it is imperative to consider the role of the kit makers in the larger context of their role in the criminal justice system. Under state action law, it is clear that "when private individuals or groups are endowed by the State with powers or functions governmental in nature, they become agencies or instrumentalities of the State."202 Under this rule, private individuals or corporations become agencies or instrumentalities of the state if they run elections, ${ }^{203}$ manage a company town, ${ }^{204}$ or maintain a municipal park. ${ }^{205}$ In the 1970 s, the Court narrowed the class of private entities considered agencies of the government to those that exercise powers traditionally and exclusively reserved to the government. ${ }^{206}$

Even under this narrowed test, the performance of scientific testing in the course of police investigation is an activity traditionally and exclusively reserved to the government. No area is more firmly within the exclusive and traditional sphere of activity of the state than

\footnotetext{
201. Id.

202. Evans v. Newton, 382 U.S. 296, 299 (1966).

203. See Terry v. Adams, 345 U.S. 461, 466 (1953) (holding that private entities could not run primary elections so as to exclude African Americans from participating); Smith v. Allwright, 321 U.S. 649, 663-64 (1944) (holding that a political party cannot exclude on the basis of race); Nixon v. Condon, 286 U.S. 73, 89 (1932) (noting that a political party acts as the state's delegate in running elections).

204. See Marsh v. Alabama, 326 U.S. 501, 509 (preventing the owner of a company town from infringing upon the First Amendment rights of leafleteers).

205. See Evans v. Newton, 382 U.S. 296, 299 (1966) (preventing a golf course owned and operated by a municipal government from discriminating on the basis of race).

206. See Flagg Bros., Inc. v. Brooks, 436 U.S. 149, 158-62 (1978) (finding that the "settlement of disputes between debtors and creditors is not traditionally an exclusive public function"); Jackson v. Metro. Edison Co., 419 U.S. 345, 351-52 (1974) (holding that utility companies are not subject to the public functions doctrine because traditionally the services they provide have not been provided exclusively by the state).
} 
law enforcement. ${ }^{207}$ West $v$. Atkins, ${ }^{208}$ a case involving prisons, is particularly instructive. In West, the Court held that a private physician under contract with North Carolina to provide medical services at a state prison hospital on a part-time basis was a state actor. ${ }^{209}$ The Court noted that because provision of medical care to prisoners was fundamentally a governmental activity, the provider of that care is a state actor. ${ }^{210}$ Moreover, this analysis is not altered by the fact that respondent was paid by contract and was not on the state payroll, nor by the fact that respondent was not required to work exclusively for the prison. ${ }^{211}$

Like the prison hospital, the crime laboratory analyzing evidence in the course of a criminal investigation is performing a law enforcement function exclusively associated with the government. Corporations that work hand in hand with those laboratories by providing the technology and know-how to perform DNA testing are, like the doctor in West, performing a fundamentally governmental "function within the state system." ${ }^{212}$ As a result, those corporations must be considered to be "acting on the government's behalf in the case" within the meaning of Brady. ${ }^{213}$

Aside from the historical and state action arguments, it is worth noting that several lower courts implicitly have found that private corporations act on behalf of the government when they perform DNA testing on behalf of law enforcement. For example, in People v.

207. The Supreme Court has recognized the prominence of the government's role in judicial processes generally, commenting that "[f]ew places are a more real expression of the constitutional authority of the government than a courtroom, where the law itself unfolds. Within the courtroom, the government invokes its laws to determine the rights of those who stand before it." Edmonson v. Leesville Concrete Co., 500 U.S. 614, 628 (1991). Thus, private actors using courtroom procedures, such as jury selection, may not discriminate on the basis of race in violation of the Equal Protection Clause. Id.

208. 487 U.S. 42 (1988).

209. 487 U.S. at 54. However, actors within the judicial system are not considered state actors where their relationship with the government is "adversarial." Polk County v. Dodson, 454 U.S. 312, 318-19 (1981) (holding that public defenders are not state actors while representing criminal defendants because the relation between the defender and the government is adversarial in nature). In the case of private kit makers and forensic laboratories, the relationship is entirely commercial. The laboratories buy their equipment from the kit makers. As a result, the relationship between the two is not best described as "adversarial."

210. Id.

211. Id. at 56-57.

212. Id. at 55 .

213. Kyles v. Whitley, 514 U.S. 419, 438 (1995). 
Davis, ${ }^{214}$ a conviction was reversed because Lifecodes, a private laboratory, refused to disclose statistical standards used in determining the probability of a "match." ${ }^{215}$ The court described the evidence as "'material either to guilt or punishment" " and cited to Brady. ${ }^{216}$ The court then held:

"The rule is plain that where the prosecution is permitted to call a witness, expert or not, who testifies as to a fact in issue or a conclusion to be drawn, the defendant is entitled to examine the underlying data, the basis for the testimony" or else the defendant suffers undue prejudice. $^{217}$

The Minnesota Supreme Court also has held that due process rights are implicated where information relating to testing is not revealed by private laboratories. ${ }^{218}$ Although these cases differ from the main concern of this Note-information underlying kits made by private corporations but used by state and other laboratories-they demonstrate the degree to which forensic DNA testing is considered government activity.

Given the historical and state action arguments suggesting that kit makers are acting on behalf of the government, what is the prosecution's duty with respect to Brady evidence held by them? In Kyles v. Whitley, ${ }^{219}$ the Court framed the prosecutor's duty in the following terms:

$[\mathrm{N}] \mathrm{o}$ one doubts that police investigators sometimes fail to inform a prosecutor of all they know. But neither is there any serious doubt that "procedures and regulations can be established to carry [the prosecutor's] burden and to insure communication of all relevant information on each case to every lawyer who deals with it.",220

The Supreme Court thus insisted that the prosecutor "establish regulations and procedures" for obtaining information from other law enforcement agencies, which, as was established above, should be un-

\footnotetext{
214. 601 N.Y.S.2d 174 (App. Div. 1993).

215. Id. at 175 .

216. Id. (quoting Brady v. Maryland, 373 U.S. 83, 87 (1963)).

217. Id. (citations omitted).

218. State v. Schwartz, 447 N.W.2d 422, 427 (Minn. 1989) ("The fair trial and due process rights are implicated when data relied upon by a laboratory in performing tests are not available to the opposing party for review and cross examination.").

219. 514 U.S. 419 (1995).

220. Id. at 438 (quoting Giglio v. United States, 405 U.S. 150, 154 (1972)).
} 
derstood to include private forensic technology companies that participate in testing. ${ }^{221}$

But the Supreme Court seemed to say more than that the prosecutor has a duty to search for the relevant information; the Supreme Court assumed that these regulations and procedures would enable the prosecutor to discover the information. ${ }^{222}$ As a result, the Supreme Court created no room for failure. The core inquiry made by a Court hearing a Brady claim does not relate to the prosecutor's conduct; it relates to the "character of the evidence that [the prosecutor] has withheld." 223

What "character" defines Brady evidence? Evidence must be disclosed under Brady where it is "material either to guilt or punishment." The Supreme Court has identified two concerns underlying materiality of evidence: whether the evidence could have changed the outcome of the trial, and whether the court could make an accurate and fair ruling without the evidence.

The Court described the first concern in United States v. Bagley, ${ }^{224}$ where it wrote that "evidence is material only if there is a reasonable probability that, had the evidence been disclosed to the defense, the result of the proceeding would have been different. A 'reasonable probability' is a probability sufficient to undermine confidence in the outcome." 225 Where information sought by the de-

221. See United States v. Santiago, 46 F.3d 885, 893 (9th Cir. 1995) (holding that the prosecutor is obliged to search prison, probation, and parole files); United States v. Brooks, 966 F.2d 1500, 1502 (D.C. Cir. 1992) (describing the prosecution's duty to search for evidence even when that evidence is "in the possession of agencies other than the prosecutor's office"). In Brooks, the court noted that "[ $\mathrm{t}]$ he cases finding a duty to search have involved files maintained by branches of government "closely aligned with the prosecution." Id. at 1503 (quoting United States ex rel. Smith v. Fairman, 769 F.2d 386, 391 (7th Cir. 1985)).

222. For an argument that prosecutors are not able to secure all relevant information from other law enforcement agencies, see Stanley Z. Fischer, The Prosecutor's Ethical Duty to Seek Exculpatory Evidence in Police Hands: Lessons from England, 68 FORDHAM L. REV. 1379, 1415-16 (2000) (arguing that the American system should take lessons from the English system, which provides for a comprehensive regulatory framework for police recordkeeping and revelation of case information to the prosecutor).

223. Brown v. French, 147 F.3d 307, 312 (4th Cir. 1998) (holding that the reason for failure to disclose is insignificant where the evidence sought was not favorable to the defendant, because the character of the evidence is the primary consideration in establishing a Brady violation).

224. 473 U.S. 667 (1985).

225. Id. at 682 . Earlier cases held that the degree of materiality required depended on the specificity of the disclosure request. $I d$. at 681 . The specificity of the requests was divided into three categories: specific requests, general requests, and no requests. Id. at 682 . In Bagley, the 
fense could result in evidence against the defendant being ruled inadmissible, that information usually will have "a reasonable probability" of altering the outcome of the case. In United States v. Yee, ${ }^{226}$ the district court addressed the materiality of data that challenges the admissibility of DNA evidence:

If [defendants] prevail in their challenge to the government's proffer of that evidence, the likelihood of conviction will be diminished substantially, if not eliminated. The opportunity for the defendants to make an effective challenge, and, more importantly, the ability of this court to resolve the issue of admissibility fairly, depend on prehearing access by defense counsel and their experts to the materials that are the subject of their discovery request. ${ }^{227}$

Although the probability that the exclusion of DNA evidence would have changed the course of the trial will vary from case to case, there are certainly many cases in which the prosecution relies heavily on DNA evidence. In most cases in which the evidence is present, it forms a strong part of the prosecution's case-in-chief. As a result, information that bears upon the admissibility of that evidence must be considered capable of altering the outcome of the trial.

The Yee court also referred to the second concern underlying the materiality requirement: the ability of courts to find the truth. The Court's most recent word on the subject came in Kyles $v$. Whitley, ${ }^{228}$ where the Court emphasized, "The question is not whether the defendant would more likely than not have received a different verdict with the evidence, but whether in its absence he received a fair trial, understood as a trial resulting in a verdict worthy of confidence." 229 The possibility of a fair trial is certainly reduced where information related to the value of scientific evidence is withheld from the defense. In its order granting discovery to the defense, the Yee court wrote, "The precondition to reaching a correct decision concerning the admissibility of the DNA evidence in this case is ... a record that is as complete and clear as is reasonably possible." ${ }^{, 230}$ Where creating a

\footnotetext{
Court established that one standard of materiality would apply to all disclosure requests, as well as failures to request. Id. at 682-83.

226. 129 F.R.D. 629 (N.D. Ohio 1990).

227. Id. at 636 .

228. 514 U.S. 419 (1995).

229. Id. at 434.

230. 129 F.R.D. at 631.
} 
complete and clear record requires the prosecution to provide evidence in the possession of law enforcement, under Brady the prosecution must do so.

Finally, requiring the prosecutor to obtain this information from the sellers of the kits serves the fundamental goal of due process: ensuring a fair trial. Requiring disclosure is the only way to ensure that private corporations do not play too great a role in the administration of justice. In Kyles the Court wrote: "any argument for excusing a prosecutor from disclosing what he does not happen to know about boils down to a plea to substitute the police for the prosecutor, and even for the courts themselves, as the final arbiters of the government's obligation to ensure fair trials." ${ }^{231}$ The role of the courts as the arbiters of the government's obligation to ensure fair trials is equally imperiled by private corporations.

\section{CONCLUSION}

As scientific evidence becomes more prominent in the courtroom, subpoenas to corporations in possession of scientific information are likely to issue with greater frequency. This conflict promises especially grave consequences in the area of criminal prosecutions, where science may be used to secure a sentence of imprisonment or death. Although courts desire to preserve a space for innovation in forensic and other sciences likely to increase the efficacy of the criminal justice system, this need must be balanced against the rights of defendants to challenge scientific evidence against them. In the end, the intellectual property rights of corporations must give way to the constitutional rights of the accused. 